\title{
An Exceptional Strike: A Micro-history of 'People versus Park' in Madagascar
}

\author{
Genese Sodikoff ${ }^{1}$ \\ Rutgers University, Newark, U.S.A.
}

\section{Introduction}

The Special Reserve of Andasibe lies on the outskirts of a Malagasy railway town whose train station doubles as a restaurant-hotel (figure 1). The station's teak floors and rafters, its resplendent bar and grandiose murals, conjure up visions of colonial officers waiting at their leisure for the steam locomotive. The nearby forest reserve shelters the indri lemur (the largest of Madagascar's primates) and an orchid park. It is a fragment of a larger protected area which encompasses a montane rain forest named Mantadia. Opposite the entrance to the Special Indri Reserve stands the office building of an office of the Integrated Conservation and Development Project (ICDP) whose administrators and staff oversaw the protected area from 1992 until 1997 (figure 2). In Madagascar, ICDPs aim to reduce pressures on rain forests caused by tavy, a form of shifting, swidden horticulture long identified by scientists as the principle cause of forest erosion since the island's colonization by humans some 2000 years ago.

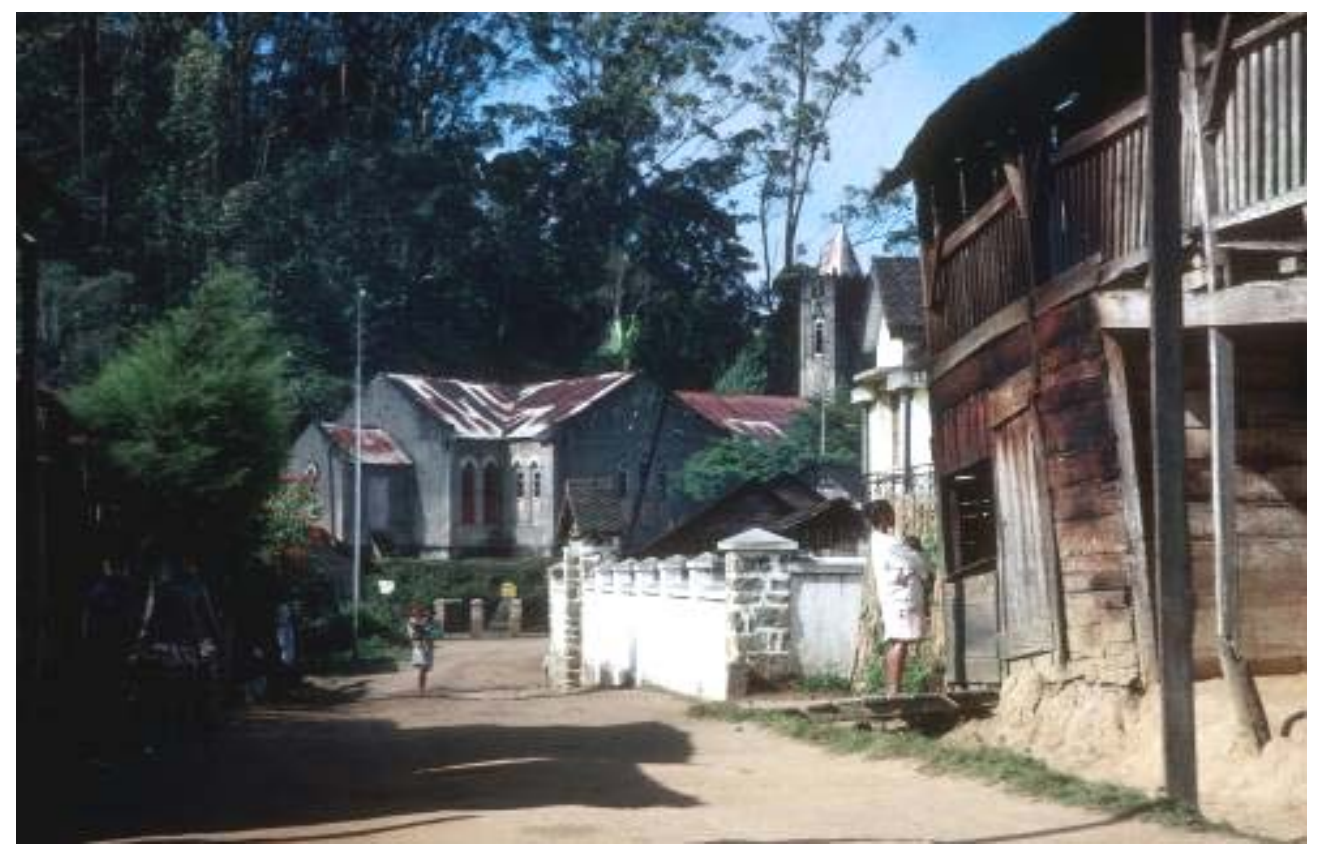

Figure 1. View of the town of Andasibe (or Perinet), a popular destination for tourists heading to the east coast of Madagascar (Credit: Genese Sodikoff, 1994).

Trash bins painted to look like startled indri faces peered from the project office veranda in the summer of 1997. A mural of a rain forest adorned the building's back wall like a mirror reflecting the nature reserve across the road, save for the absence of people: no foreign tourists, guides, biologists, school children, project workers, or conservation scofflaws. The contrast between reality and mural was especially stark that day, as a crew of manual workers toiled away on the grounds of

1 Department of Anthropology and Sociology, Rutgers Univ., 360 Martin L. King Blvd., Hill Hall Rm. 603, Newark, New Jersey 07102-1801, USA. sodikoff "at" andromeda.rutgers.edu. Field research was supported by a grant from the IIE Fulbright Program (1994-1995) and from the Institute for Global Studies in Culture, Power, and History at the Johns Hopkins University (1997). I am grateful for the assistance of numerous people, especially Hajamanana Rakotoniasy, Ndranto Razakamanarina, "Bekapoaka," Dick Ford, Barbara ThomasSlayter, Dianne Rocheleau, Gillian Feeley-Harnik, and Sara Berry. I also thank the two anonymous reviewers of this article for their thoughtful suggestions. 
ICDP project office, the former forest station of Analamazoatra. The crew was in the process of renovating the building and beautifying the entrance to the reserve.

The American nonprofit consultancy organization (a species of "nongovernmental organization") leading the project and was nearing the end of its contract. ANGAP (Association Nationale pour la Gestion des Aires Protégées), the newly created Malagasy park service, was about to take over the reins of the project. The office building had aged rapidly in the two years since I had last seen it in 1995. The walls were cracked, the running water had stopped, and mud oozed up from the mosaic marble floors. About thirty unskilled conservation workers (ouvriers), along with masons and carpenters brought in for the task, were strenuously hammering posts into the ground, filling holes with cement, and erecting a low brick wall, while others crushed rocks with spades to make gravel.

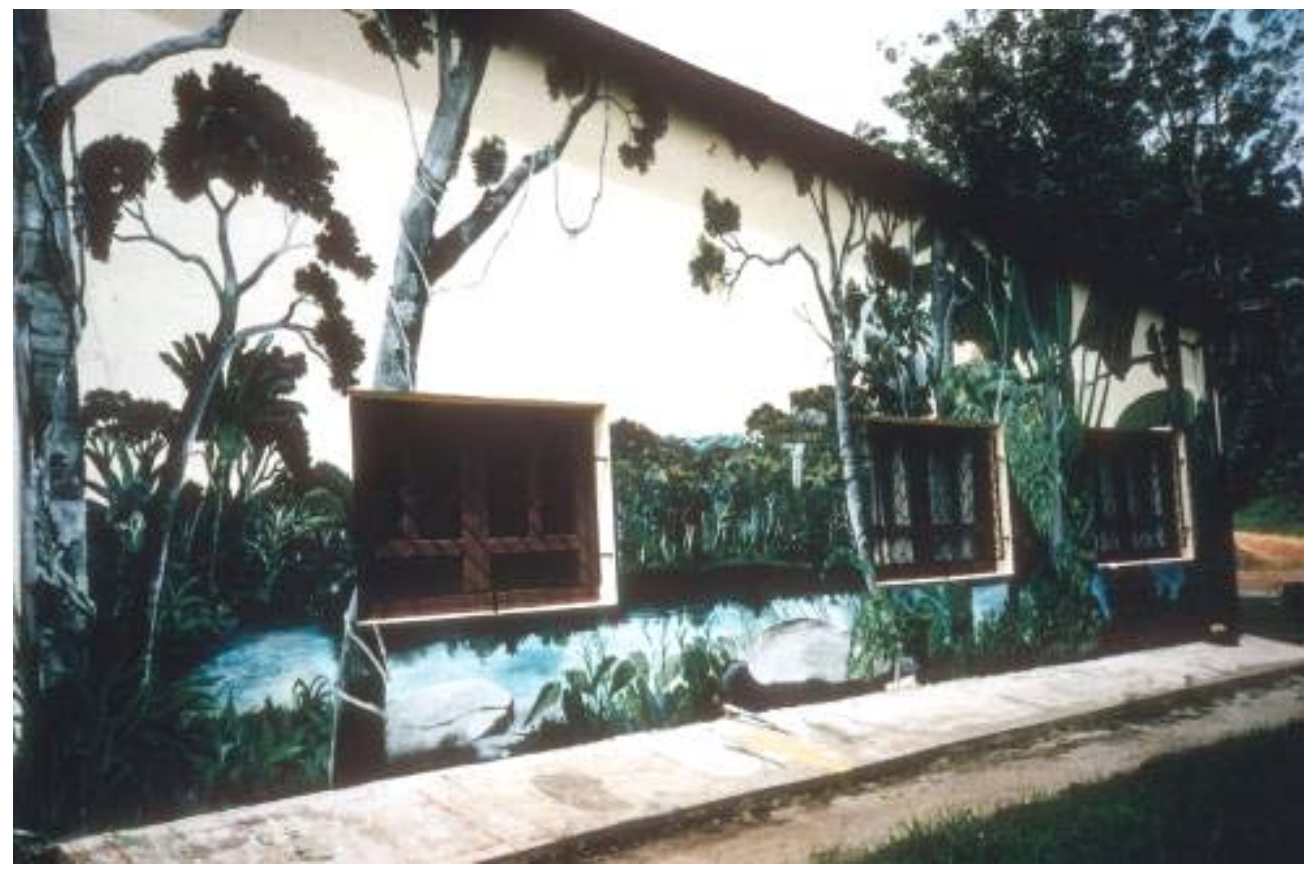

Figure 2. Back of the project office building at the Analamazoatra forest station, near Andasibe, Madagascar (Credit: Genese Sodikoff, 1995).

Meanwhile, in the offices, the project's "bureaucrats" (as they were called by lower-tier employees), the accountants, team leaders, secretaries, and computer technicians, were playing computer games. The dilapidated project headquarters, a structurally unsound building, served as a fitting metonym for the ICDP as I had come to know it.

This trip of mine was brief, a follow-up visit to my ten-month period of Masters thesis research between 1994 and 1995. I learned, to my surprise, that thirty-nine of the lower-tier workers, some of whom I had come to know during my earlier fieldwork, had recently staged a strike against the project's management. They felt they had to do something big to jostle the American Head of Project out of his apathy and to restrain the power hunger of his Malagasy counterpart, the Director, who handled the personnel and daily operations of the project. The strike, ultimately, was no revolution. It did little to change the conservation bureaucracy over the last ten years, yet it divulged a side of conservation long obscured by the specter of global rain forest erosion.

I offer here a microhistory of neoliberal conservation politics in Madagascar. The article microscopes the lives of low-wage conservation workers grappling with economic changes since decentralized forest governance had been put into effect, and their tenured civil service jobs in the forest department had devolved to a short-term contractual job with a foreign NGO. The microhistory of the work strike represents a microcosm of widespread trends in Madagascar's biodiversity 
protection program. It brings to light the "inner, structural elements of a larger social whole" (Peltonen 2001: 349). ${ }^{2}$

The case, moreover, fills a gap in political ecology and the "grey" literature of conservation and development, the latter term referring to the unpublished field reports and evaluations of conservation and development institutions. The gap concerns the subject of labor in conservation efforts, which are integrally tied to the development of green capitalism in rain forest regions. Conservation, I argue, devalues labor as a factor of production, and labor's devaluation poses obstacles to the longevity of green capitalism in poor countries such as Madagascar.

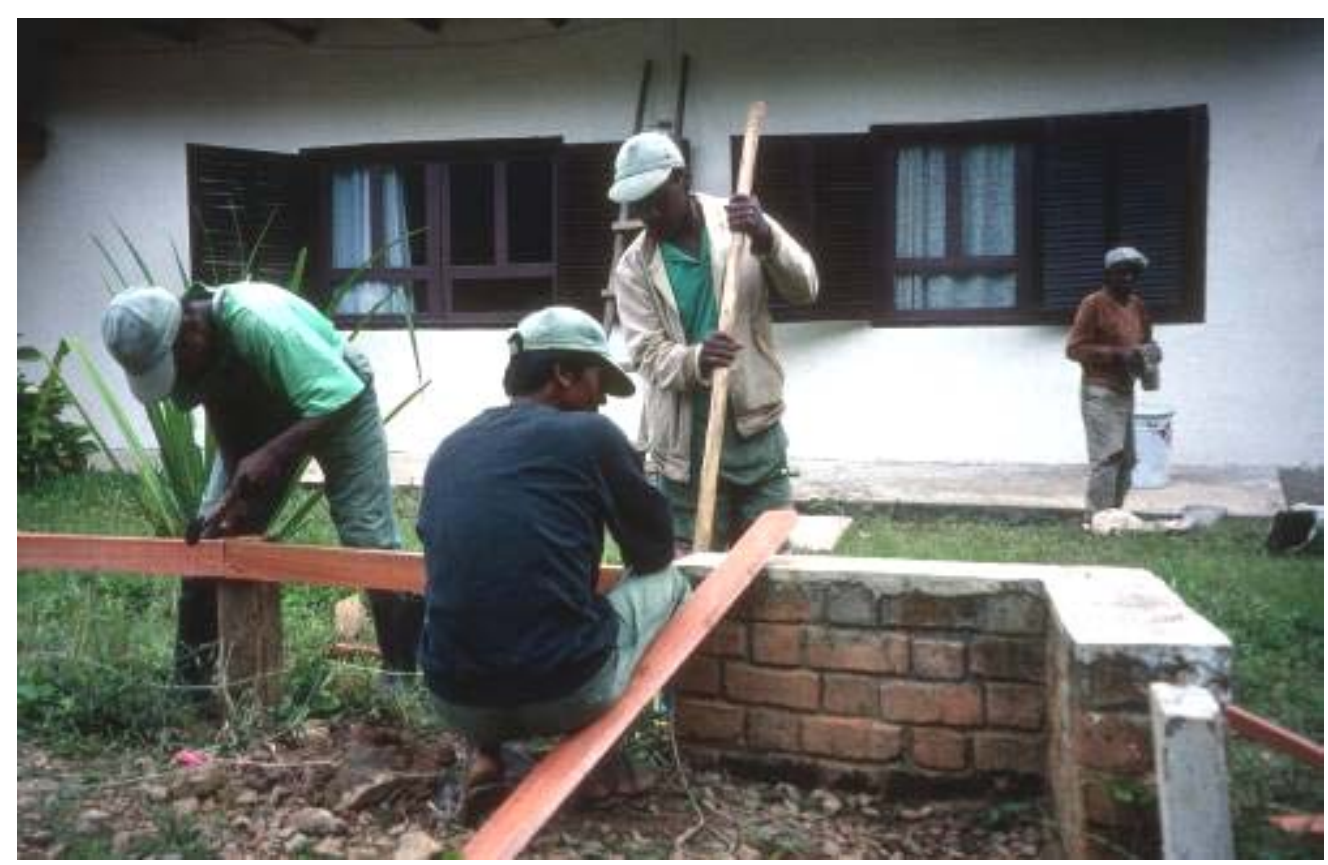

Figure 3. ICDP workers at Andasibe-Mantadia rehabilitating the office and grounds (Credit: Genese Sodikoff, 1997).

Green or ecological capitalism in the tropics, exemplified by industries such as ecological tourism and biological prospecting, relies on the exchange value of intact rain forests rather than that of extractable forest resources (Escobar 1997). Concerning bioprospecting, Cori Hayden (2003: 49) writes that it represents "one of myriad efforts on behalf of a wide range of actors to valorize nature within firmly economic renderings of accounts - that is, to argue that it is not an economic 'externality' but rather should be considered internal to, and thus managed through, market processes." In similar vein, rain forests become destinations for ecological and adventure tourists, or "experiential" commodities (West and Carrier 2004).

Over the course of my anthropological research in Madagascar, beginning in 1994, I discovered that low-wage conservation workers (figure 3 ) have felt themselves to be devalued by their structural superiors despite the critical role they have played on the front lines of forest conservation. As I will show, the oral histories of conservation workers at Andasibe express how institutional devaluation molds subjective experience.

While scholars and practitioners of rain forest conservation may contend that local, manual labor constitutes a relatively minor issue in the global endeavor of protecting biodiversity, I argue that its role is key. Frontrunner microhistorians, such as Carlo Ginzburg (1980), Giovanni Levi (1991),

2 Findings are based on twelve months (1994-1995, 1997) of ethnographic research in the AndasibeMantadia Protected Area conducted for a Masters thesis in International Development at Clark University. This article is also informed by later dissertation fieldwork (2000-2002) in Mananara-Nord, Madagascar, where I conducted fourteen months of ethnographic fieldwork in a UNESCO Biosphere Reserve for my doctoral dissertation (University of Michigan, 2005). Research methods at Andasibe consisted of participant observation, structured and unstructured interviews (in French and Malagasy), the collection of oral histories, and photography. Taped interviews were conducted with and later transcribed by a Malagasy research assistant. I use pseudonyms for all individuals mentioned at Andasibe. 
Natalie Zemon Davis (1983), and Jacques Revel (1996) have argued that a methodological focus on exceptional individuals helps to dismantle an historiographical paradigm in which the "average" or "normal" is seen to best describe society at a particular point in time (see Auerbach 2003). These scholars contend that the "average" is itself a construct which obscures the extent to which seemingly extraordinary social practices, beliefs, or experiences permeate and forge society. The search for the so-called "normal exception" in the archives challenges the perspective that outliers are marginal to social life, to the ways in which persons apprehend and act in their social worlds (Findlen 2005: 233; Magnusson 2006).

The "microelements" (Peltonen 2001: 351) of this study include (1) the focus on locallyhired, low-wage conservation workers, a category of unskilled worker that accounts for a small percentage of expenditures for Madagascar's biodiversity conservation program; (2) a focus on one staff of conservation workers in Madagascar; (3) the reduced temporal frame of the narrative, which relates details concerning a month-long event; (4) the reduced spatial frame, in that the strike occurred in one protected area; and finally (5) the focus on labor within one national economic sectorconservation and development. The microhistorian's arguments enable us to understand why an apparently anomalous event-a strike in a rain forest-is symptomatic of the larger problem concerning the conceptualization and politicization of rain forest and biodiversity conservation efforts.

\section{Conservation and the Labor Question in Africa and Madagascar}

Although historical studies of conservation in Africa, the Americas, and Asia do not explicitly focus on the labor of ecological conservation, they reveal the intrinsic relationship of state labor regimes and land degradation. Economic exploitation by capital and state authorities has historically exacerbated poverty by alienating peasants from the means of subsistence, including land, stock, and their own labor for agriculture (Egboh 1979-1980; Beinart 1984; Peluso 1992; Sivaramakrishnan 1999; Tropp 2003). Colonial entrepreneurs and states procured labor from among pastoralist and horticulturalist societies as they developed colonial infrastructures, industries, and forms of land management which degraded local ecosystems. Erosion and species loss belied the rhetoric of progress tied to colonial development schemes (Beinart 1984; Jarosz 1993; Bryant 1996).

Conservation has represented one means by which colonial states attempted to manage agrarian populations and regulate "their position within the emerging capitalist social order" (Munro 1998: xxxviii). From the perspective of administrators and environmentalists, however, conservation has been treated as a remedial action and moral imperative, an antidote to the deleterious effects of resource extraction and swidden agriculture. In general, conservation has not been treated as a form of production in its own right. I suggest that the difficulty in imagining forest conservation as a form of labor and value production stems from an illusory idea that conservation entails the removal of people from the forest so that it can regenerate undisturbed. While removing subsistence farmers from forests represents a key strategy of biodiversity protection, the other side of this strategy involves the installation of a labor force that will lay the groundwork for forest-based capitalism. While ICDPs procure labor from the subsistence sector to police forest spaces, a more obscure service performed by manual labor involves making rain forests legible and accessible to tourists. The protective dimension of conservation veils its productive dimension. In the planners' imagination, the environment and development sector appears the last conceptual holdout of a labor-less Africa.

By this I allude to Frederick Cooper's (1996) argument in Decolonization and African Society, in which he tracks the emergence of the "labor question" in the discourses of colonial administrators. The question concerned "the relationship of how people worked to the way they lived, to the expectations they brought to the workplace, to the ways in which they experienced the power of employers and colonial officials, to the relationships they formed and the aspirations they acquired through employment and urban life, and to the ways they reproduced themselves" (Cooper 1996:23). During the early decades of rule, when colonial settlers sought labor for capitalist enterprises and infrastructural projects, British and French colonial administrators imagined African workers as essentially "tribal" subjects, as "dangerous primitives or demagogues," far removed from the working classes of Europe (Cooper 1996: 18). In Madagascar, as elsewhere, colonial administrators lamented their inability to mobilize voluntary and industrious bodies for incipient industries and public works projects. They consequently enacted more labor laws there than in any almost any other French colony (Feeley-Harnik 1984: 6).

The distinction colonial authorities made between European workers, who constituted a viable working class, and African workers, who yielded brute labor power, manifested in authorities' inability to transpose the concept of labor rights from the metropolitan context to the colonial one. But beginning in the late 1930s, Africans organized strikes and unions to resist colonial labor practices. They articulated the humanist rhetoric of rights that forced officials to confront Africans as proletarians. The ideological shift made way for a political one: a codification of labor practices, 
support of trade unions, and institution of a living wage. As the demands of African labor grew more insistent, threatening, and costly, the colonial administrations "both disavowed responsibility for raising the colonial standard of living to European levels and moved away from the metropolitan standard as a measure of wages" (Cooper 1996: 452). The colonies no longer seemed profitable sites for French and British enterprises.

In Madagascar (figure 4), the politicization of African labor during the years prior to World War II gained momentum through a nationalist movement aided by smaller political groups, such as the Malagasy Communist Party (Randrianja n.d.). The movement met a dire fate during the bloody uprising of 1947, when Betsimaraka people on the east coast killed 550 French over twenty months of fighting. The French retaliated more brutally with torture and execution. Nearly 100,000 Malagasy lives were lost (Tronchon 1986; Cole 2001: 61). Not only did post-war insurrections by labor, peasants, and youths in Madagascar and Africa confirm for Europeans the benefits of decolonization and indirect rule. They also enabled colonial administrations to evaluate who among the nascent African political parties would best serve European interests after independence.

In response to the 1947 revolt in Madagascar the French quashed the leading nationalist party (Mouvement démocratique de la rénovation malgache, MDRM) thus leaving an opening for its rivals, particularly PADESM (Parti des deshérités de Madagascar, later becoming the Parti socialdémocrate), the party of pro-French Philibert Tsiranana, who won the presidency upon Madagascar's Independence in 1960. He was ousted in the May Revolution of 1972, signifying a widespread sense of disillusionment.

Madagascar's socialist era, commencing with an unstable, revolutionary period (1971-1975), had embroiled the country in political violence. After the assassination of Colonel Ratsimandrava, who held office for less than a week in 1975, Didier Ratsiraka was named president. Rejecting colonial ties to France, Ratsiraka designed his early policies against French models, inducing much foreign capital to pull out of Madagascar (Sharp 1993). While an anti-colonial stance served Ratsiraka by offering a stark contrast to what came before, he, like leaders before him, tapped French revolutionary discourse to advance his cause. As Lesley Sharp points out, revolutionary France has long provided ideological models for Malagasy. Manassé Esoavelomandroso (1990) argues that as far back as the nineteenth century, Merina royals struggled to comprehend the image of France as both "advocate of the rights of humankind and a colonizing nation" (Sharp 2001: 210). Sharp writes: "the French, in turn, struggled to construct a portrait of an indigenous Malagasy character in reference to Enlightenment ideals, one that ultimately grated against their own charter on the International Rights of Man" (ibid.).

Ratsiraka sought to depart from the past by adopting the socialist rhetoric of contemporary African leaders. He advocated isolationism and self-sufficiency. He promised a "proletarian revolution" involving the devolution of power from the state to the "people." After the May Revolution, officials had imagined revitalizing the institution known as fokonolona, denoting an ancient council of village elders, which would oversee units analogous to rural Soviets. Lacking political cadres to guide the fokonolona in 1974, however, Ratsiraka promoted the idea of development being handed over to a larger administrative unit, the fokontany, "the people," which today maintains public security and law at the level of the village or hamlet (Laymaire 1975; Gow 1997: 413; World Bank 2004: 15).

Feeling threatened by Ratsiraka's radical vision of autonomous fokontany and the loss of authority it would entail, officials opposed his plan. Although the Merina bourgeoisie of Antananarivo supported nationalization and the state's seizure of land held by the French, they were not ready to embrace Marxist ideology and socialist policy (Gow 1997: 418). Nevertheless, by 1976, Ratsiraka's party introduced charters to transform Malagasy society, implementing the fokontany and fokonolona institutions as a means to install political allies in communities around the island. The process of nationalization moved forward and sank the nation into debt. Educational standards deteriorated, the fokontany development schemes floundered, and educated graduates, unable to find employment, joined the bloated ranks of the civil service (Gow 1997: 420).

By 1980, real producer prices for agricultural exports - the agricultural sector accounted for eighty to ninety percent of employment and exports-had fallen so low that the state could no longer meet its payment obligations to international creditors and donors (Barrett 1994). Economic crisis forced Ratsiraka to turn to support from the Bretton Woods Institutions, and a four-year period of stabilization ensued. Until 1986, Ratsiraka's strongest allies included Eastern European countries, the People's Republic of China, and North Korea (Sharp 1993; Covell 1987: 29-75). But by 1986, liberalization measures, including decentralization, deregulation, privatization, the establishment of free trade zones for foreign businesses, and the revitalization of environmental conservation efforts were in full effect (Kull 1996). Almost inaudible now were the political discourses of trade unionism, egalitarianism, and agrarian solidarity. 


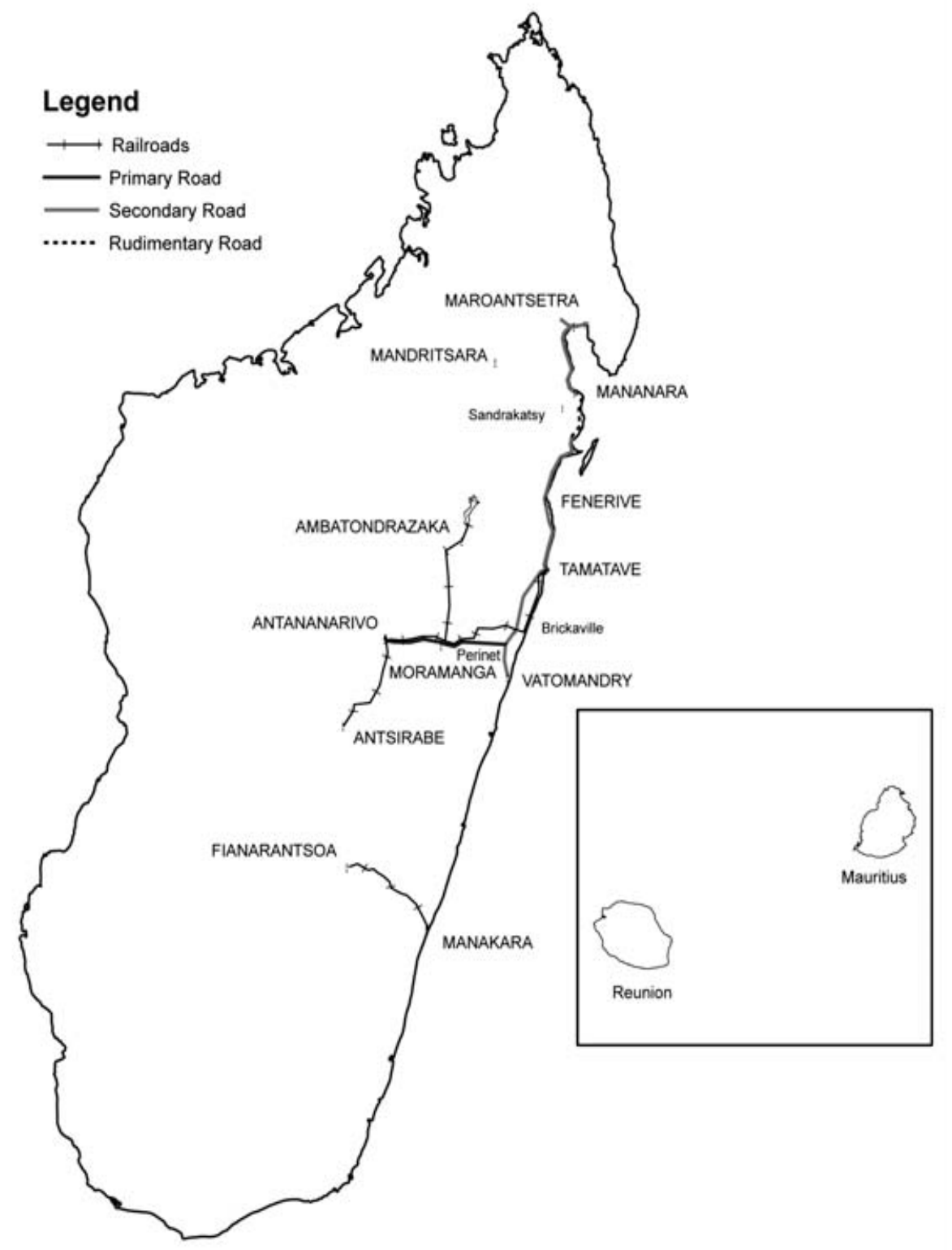

Figure 4. Map of Madagascar showing town of Perinet (Andasibe), on the national route and railway line that links Antananarivo, the capital, to the east coast. (Map made by Karl Longstreth of the University of Michigan Map Library using ARC GIS software and data from ESRI Inc., as well as public data sources.)

Globalization has weakened the forty year old trade union movement throughout Africa and the world. François Misser (2000) writes that the trend towards privatization in Africa results in reduced staffing and therefore lowered membership levels in unions. In the Export Processing Zones (EPZ) of Mauritius and Madagascar, for example, unions are often prevented from organizing within firms with EPZ status. He relates that "Malagasy trade unionists say that the situation is much worse in their country. Employers pay salaries which are well below the official minimum wage. Workers who want to take leave for medical reasons risk losing their jobs" (Misser 2000: 31).

The events of the past contributed in some measure to the views of Malagasy workers caught in the current of political change in the 1990s, when the collapse of state socialism had cleared ground for a new moral vision: biodiversity conservation (Kull 1996). Intensifying global anxiety over species and wilderness loss, particularly in tropical zones, complements globalization in the former 
"Third World." Older political imperatives of state welfarism and labor rights have to a large extent been supplanted by the moral urgency of extinction, for which ecological industry and transnational capital are seen as the best palliatives.

The case presented here suggests how ripping the security net of state and trade union services jeopardizes pursuits as ostensibly ethical as biodiversity conservation. The significance of labor as a social issue puts under scrutiny the extent of capital's commitment to environmental goals. An analysis of decentralized environmental governance and its division of labor offers a new perspective of "people and parks." It turns the analytic model of resistance inward.

\section{Reframing "People versus Parks"}

Political ecologists have produced a growing literature on the dynamic of "people and parks," elucidating the political economic and moral reasons for which the poor resist conservation efforts around the globe (Igoe 2003; West et al. 2006). We learn how states deploy conservation as a means of subjugating peasantries and monopolizing control over land (Peluso 1992; Neumann 1998; Munro 1998; Sivaramakrishnan 1999; Harper 2002; Brockington 2002). Conservation most often involves the imposition of economic and environmental values that do not accord with residents' mores (West 2006). The moral authority of conservation typically overrides residents' land use rights and political opposition (Brosius 1999). As a matter of course, the implementation of conservation plans marks geographical boundaries and frequently reinforces social divisions with greater success than persuading horticulturalists to adopt conservationism (Marcus and Kull 1999; Moore 1993; Neumann 1997).

Community conservation initiatives, in many ways a beacon of hope for conservation planners (Brosius et al. 2005), often disappoint residents of protected areas because they stipulate rigid rules for participation in park management, tend to solicit the participation of the most vocal or powerful (male) villagers (Ghimire 1994; Larson 1994; Schroeder 1999; Walley 2004), or disparage the expertise of local residents. With the linkage of conservation to development activities, residents frequently find that project representatives expect them to volunteer labor and raw materials in the name of the public good (Scott 1985).

With reference to Madagascar, anthropological and geographical studies of ICDPs demonstrate how ecological tourism in national parks drives up the market prices of staple foods and medicines for Malagasy residents (Hanson 1997), and alienates people from resources they need to survive (Harper 2002). Analyses furthermore unknot the complex ties among global environmental organizations and state agencies. Christian Kull (2004), for example, addresses macro-level political relations among national and international representatives, while Lisa Gezon (1997) examines relations among institutional levels, which frequently cause problems of non-coordination or tensions between different ranks (see also Brockington 2002). Scholars demonstrate how cultural differences between expatriates and nationals complicate the administration of environmental projects.

People's resistance to conservation, the subject of devastating critique, has come to preoccupy conservation's practitioners, who acknowledge the need for collective bargaining with farmers but not with workers (see Richard and Dewar 1996; Thurow 1991). What is left largely unexamined is the role of locally-hired, cheap labor in ICDPs, usually recruited from the subsistence sector (see Taylor 1999). At this historical juncture, I believe it is necessary to widen the aperture of our analysis to the social organization of the conservation bureaucracy. At the heart of conservation activities are labor relations, and these pose ethical questions that sit uneasily with the ethical rationale of conservation.

A notable exception to my claim that political ecology has omitted the labor question in studies of conservation is Michael Dove's institutional ethnography of the forest service in Pakistan (1992, 1994, 2005). Dove looks at labor relations, concentrating on the dynamic between foresters and farmers. He argues that higher-level foresters, who wield great authority in rural areas, tend to display class favoritism by demeaning peasants' "lack of tree-mindedness" while opting to funnel state resources (such as tractors, low-interest loans, and other subsidies) to the rural elite. Foresters recognize that ecological transformation has entailed both the depletion and relocation of natural resources from state domains to private landholdings, a trend which threatens the forest service because its "political capital" has depended on controlling forest area and the rents it provided (Dove 2005: 223-224).

The phenomenon of decentralized forest management in Madagascar, as in other rain forest countries, provides a very different context than the one examined by Dove. Similarities between the high-level Pakistani foresters and Malagasy foresters exist (the elite forester cadre in Madagascar has assumed many of the ICDP directorships), but class divisions within the agrarian sector are more subtle in Madagascar. More importantly, for the purposes of conservation, foresters are not the ones who interact with peasants. Instead lower-tier workers of conservation and development projects do. 
One sees class homogeneity among this group, and only slight class differentiation between lower-tier ICDP workers and their objects of intervention, peasant farmers. Many manual conservation workers have spouses who practice horticulture, or else rely on extended kin networks for subsidies of rice, the staple crop.

For these reasons, the framework of opposition, "people against parks," obfuscates issues of class interest and ideological orientation when it comes to who is intervening in agrarian societies for the purpose of forest conservation. The framework of resistance compels us to identify and analyze problems originating from "out there," in the culture and economy of dispossessed landholders or "target" populations of conservation and development schemes rather than from inside conservation institutions themselves.

"People versus parks" risks polarizing conflict and thus manufacturing a high degree of social homogenization among the advocates and detractors of conservation. I do not want to insist too heavily on the problem of dichotomization because social scientists have also taken pains to distinguish different types of NGOs and conservationists in their ethnographies (e.g. Carrier 2004; Walley 2004; West 2006). These studies demonstrate an attunement to difference and unequal social relations comparable to earlier research on target populations (e.g. Hodgson 2001; Schroeder 1999; Thomas-Slayter and Rocheleau 1998).

Another effect of the framework of "people versus parks" is that it may veil the ways in which people make parks accommodate their own cultural mores. People manage to live with parks by getting around their rigid rules and abiding by their own land and work ethics. While many residents of Andasibe outright spurned conservation rules, for example, others joined the ranks of project workers (and more would have gladly done so if given the opportunity). A focus on target populations may veil the process by which protected areas become socially integrated into regions. It may also obscure the impact of conservation's internal structure, consisting of flanks of "locals" at the front lines of forest protection, on the land. The alternative framework of "parks hire people" thus internalizes the dynamic of imposition and resistance. I return now to the ICDP in Madagascar to give an understanding of its organizational structure and its intrinsic value system.

\section{The ICDP Structure and Work Roles}

Locally-hired wage workers of ICDPs in Madagascar occupy a difficult intermediary position: They are socially and culturally tied to local communities, dependent on income from the state forest service or foreign donor organizations, committed to the meaning of their work, and cognizant of the historical, hierarchical distribution of power and privilege based on nationality, ethnicity, and access to education. They conduct the daily tasks of ecological protection and serve as the emissaries of conservationist ideas and techniques to farmers. Unskilled conservation workers live and work in protected areas. As local residents themselves, conservation agents can explain things to villagers in the regional vernacular and can bridge the social divide between villagers and urban-based officials or expatriates. Their employment ideally helps to weaken the criticism that conservation is in the interest of vazaha (foreigners, outsiders).

The ICDP of Andasibe-Mantadia oversaw both the Special Indri Reserve of Andasibe and a rainforest called Mantadia, which had become a national park shortly before the installation of the project. A non-governmental organization (NGO) based in Washington D.C. successfully bid for the contract to manage the project, which was operational in 1993 and funded mainly by the United States Agency for International Development (USAID). The NGO collaborated with several partners on the project, including Madagascar's newly created park service, the National Association for the Management of Protected Areas (Association Nationale de la Gestion des Aires Protégées, or ANGAP), new Malagasy environmental agencies, and SAF-FJKM, a Malagasy NGO affiliated with the Protestant Church of Madagascar.

The ICDP employed fifty-four people in 1997. Two were expatriates, thirty-nine of the employees were wage laborers of various ranks, and the others held higher-paid office jobs. The Malagasy Director of the project, an employee of ANGAP and former official forester, had devised an intricate set of catégories and échelons to rank each employee in the project. Job categories varied in pay and duties. Office building guardians and cleaners earned the lowest wages. Next were unskilled laborers (ouvriers), whose tasks included portage, construction, trail building and maintenance, forest surveillance, tree tagging, reforestation, and extension work with peasants. Skilled laborers (ouvriers specialisés) had more specialized training; their jobs included masonry and orchid-keeping. Paid more than the ouvriers, the conservation agents (agents de conservation)

3 SAF (Sampan' Asa momba ny Fampandrosoana) is the "Department for Development" for FJKM (Fiangonan'i Jesoa Kristy eto Madagasikara), the Church of Jesus Christ in Madagascar. 
theoretically knew more about the local flora and fauna. But their daily tasks were the same as those of the ouvriers.

Each position in the ICDP was salaried according to the nationality and education level of the employee. During the course of the project, the value of the Malagasy franc (FMG) steadily fell. From 1994-1997, one dollar could buy FMG 4,000-5,500. ${ }^{4}$ The American Director and his Deputy Director (also American) earned annual salaries of US\$80,000 and $\$ 55,000$ respectively, lived in modernized houses in the nearest town with rents paid by USAID, had the use of project vehicles and chauffeurs, and received per diem during stays in the capital. The Malagasy Director, an employee of ANGAP, earned the approximate equivalent of \$6,000 annually, monopolized a project chauffeur and vehicle, owned a large house in town, and, according to workers, found creative ways to pad his salary through the project and the ticket revenues of the nature reserves.

True to the Malagasy proverb, "those around the forest don't have big houses," the project laborers lived in much humbler accommodations (figure 5). Without university or professional diplomas, these workers earned an equivalent of between \$240 and \$390 annually. All low-wage workers of the ICDP The typical house of a wage worker consisted of a simple, square wooden structure raised a couple of feet off the ground on wooden stilts with a shallow veranda and uneven floorboards. The plank walls were insulated with reed mats and decorated with magazine cutouts or the faded publicity flyers of presidential candidates. Possessions typically included a couple of bed frames with sponge-foam mattresses, a wooden table and chairs, a few worn plates and utensils, two iron pots, and a charcoal stove.

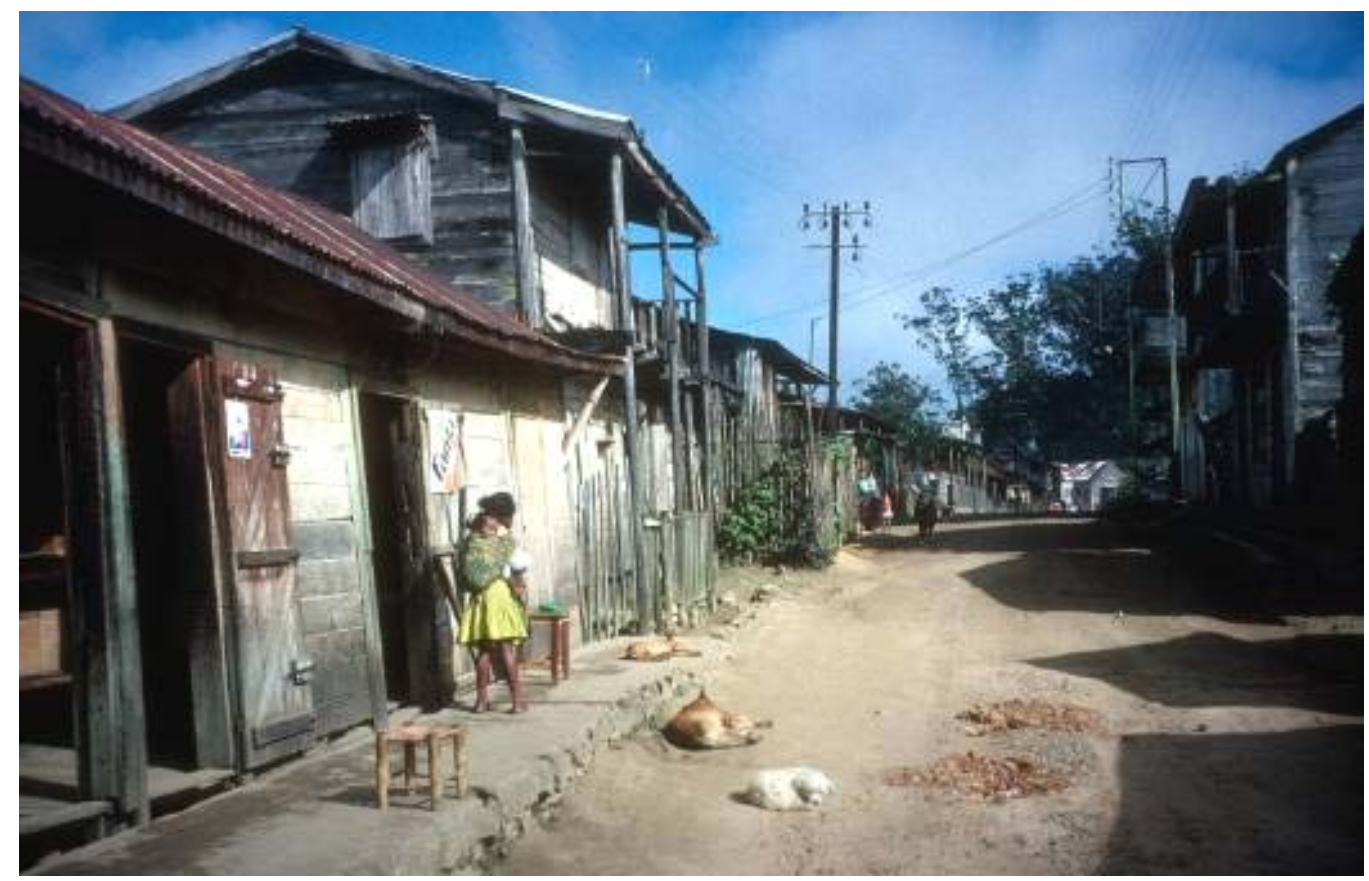

Figure 5. View of a residential section of Andasibe (Credit: Genese Sodikoff, 1994).

Most of the project employees had worked in the local forest service between six to ten years before signing a contract with the American NGO assigned to run the ICDP. Many of them came to Andasibe as forest service employees. The forest service (Eaux et Forêts) insisted that the NGO take over the payroll upon the establishment of the ICDP. By signing the NGO's contract, workers lost their more secure positions as civil servants with the forest service. On the positive side, the NGO, unlike the forest service, was required to pay at least the national minimum wage. Despite the fact that the NGO's wages were regular and higher than those of the forest service, the minimum wage was nevertheless inadequate for the cost of living in Andasibe. The town was relatively expensive due to its steady stream of European and North American tourists. The majority of the town's

4 The per capita Gross National Product in 2003 was US\$290, making Madagascar one of the poorest countries in the world (World Development Indicators database 2005). 
inhabitants earned their livelihoods from a variety of pursuits: petty trade, domestic labor, and farming in rice paddies (if one owned wet land) and on hills, where rice was intermixed with greens and vegetables. Other sources of employment in Andasibe included two graphite mines, four tourist hotels, and the Department of Public Works which expended much time and energy repairing the railway, which constantly damaged by cyclones and soil erosion. The graphite mining operations of Société Louys and Etablissements Izouard, built by two French colonial settler families, stood just beyond the center of town. People said that the sludge from the mines had choked off the crocodiles once inhabiting the river. Mr. Louys had also built a five-star hotel about one kilometer from the town center, anticipating a boom in tourism once the Mantadia national park was open. Hotel Vakona, it was named, possessed its own zoological park and abutted the primary rain forest.

The ICDP provided higher wages than jobs for unskilled labor in the French-owned mines and hotels. Unlike local Eaux et Forêts officials, foreign organizations were stringent about work rules. Employees could no longer supplement their incomes by logging (timber buyers would pay up to 25,000 FMG per log for precious hardwoods), doing tavy in the forest (workers were expected to prevent tavy in the forest), or freelance tourist guidance. Wage workers therefore faced the predicament of unsure futures and insufficient wages, largely unable to minimize their risks with supplementary livelihoods. Although management kept wage workers in the dark about their legal rights, workers eventually took action to stake out a more secure future and more livable present.

At Andasibe-Mantadia, the head of the ICDP, Albert Slater, and his Deputy were North Americans. The National Director, Hery Rasamison, like the majority of ANGAP's National Directors, was Merina, the politically dominant ethnicity of Madagascar. Below these three men, were the heads of each component of the ICDP. All were Merina, of elite social class, and male. Other administrators, such as accountants, secretaries, computer experts, and a tourism specialist, were Merina elites, predominantly male, and predominantly relatives of Hery, who accumulated clients by repeatedly persuading Albert of the need for new, high-level hires. Manual laborers comprised the lowest rungs of the wage ladder. Most of these men were born in the eastern region and were Betsimisaraka. However, several laborers identified themselves as Merina, and a few belonged to other regional groups. They had previously worked for the forest service (Eaux et Forêts) and had become NGO employees when the state obliged the NGO to take over the forest service payroll at Andasibe.

One worker, Leonard had worked in forest conservation projects since the late 1980s and was born and raised in Andasibe village. He was funny, modest, and popular, and he had standing in the community due to his father's position as the tangalamena of Andasibe, the traditional authority figure of Betsimisaraka communities. Under the NGO's contract, Leonard was an ouvrier in the project. He felt stuck in a low-paying catégorie and échelon, and was convinced the director harbored unaccountable animosity towards him. "The Dir Nat [a nickname for Hery, from Directeur National] says I drink too much, but I work hard. It's always me... Leonard do this, Leonard do that. Everyone knows I'm a hard worker, but that Hery, I don't know..." Leonard was very industrious, and I noticed that other employees often took advantage of his diligence during extended outings in villages, when they were obliged to cook and wash dishes for their Merina supervisors in the evening.

As an ouvrier, Leonard's position was a category above a guardien or femme de ménage (cleaning woman), the lowest categories. In the summer of 1997, he earned monthly wages of 206,000 FMG (approximately \$41), plus 15 percent of wages for a lodging indemnity. Both ouvriers and agents de conservation had essential roles in forest protection, which they considered the real work of conservation, unlike the report writing of the town-dwelling "bureaucrats." Raymond, an agent de conservation, described his forest surveillance responsibility:

If there's someone who steals [timber] during the night, I have to wake up to work. You know if someone is stealing by the sound of the axe, which can be heard from the village. Or, there's someone who comes to tell you. That already happened once. I didn't dare fight with the thief because we don't have weapons, but we just look at the thief to recognize him and write a report the next day. The project didn't give us flashlights. We have to use our own.

Raymond's position as agent de conservation entailed the same responsibilities as an ouvrier like Leonard but was better paid. Earlier, he had gained experience as a guide for two American primatologists studying species of cohabiting lemurs in the Mantadia forest. This experience, and his ability to speak some French, earned him his job classification.

Raymond cited the contradictions in the project's goals. He criticized ANGAP's blockage of funds that had been allotted for development activities in villages. The money came from tourist entry fees for the Special Reserve. Originally village residents in the region were promised fifty 
percent of the park entry fees, but ANGAP argued it needed a greater percentage of revenue to run itself, implying that effective bureaucratic structures were more essential to conservation than community development. At the same time, conservationists at ANGAP and other agencies insisted that tavy was the greatest threat to the forest. "It's difficult," Raymond said, "because they promise to give the villagers [park entry fee] money, but afterwards they invent stories to take it away... There's something wrong with the management of this money." He continued:

Forest conservation depends on us. We're the ones who directly talk about it to peasants, and not the Directors, who don't even know how to protect this forest. Since we don't have money to give peasants, we can't convince them. And we speak with them of the importance of the forest when we meet them, when we drink with them, sometimes we visit them at each household. That succeeded...

Raymond felt that the project's unfulfilled promises undermined his and other conservation agents' credibility and relationship to peasants. In January of 1997, Raymond had been instrumental in organizing workers to demand raises and rights. He said he "wanted to do something for the little workers" like himself.

Herisoa, a longtime forest service employee and an ouvrier specialisé (an échelon above ouvrier) was very familiar with the corruption of ex-officials from Eaux et Forêts. He feared that the transfer of the conservation project to ANGAP, or any other Malagasy organization, would have destructive consequences on the forest. He recognized that foreign conservation agents lay the foundation for these consequences despite their speeches about the need to protect the environment. Musing on the recent history of foreign intervention in the Andasibe-Mantadia region, Herisoa claimed: "foreign NGOs that come here to protect the environment do their work well, but there isn't any follow-up. They're happy with just coming along and not getting too involved." By saying foreign organizations "do their work well" Herisoa meant that he trusted foreign more than Malagasy managers to follow donor mandates and rules. Foreigners have tended to enforce rules more stringently than Malagasy forest service officials. The point about foreigners not getting involved in the daily work and politics of the project indirectly indicted Albert Slater, an infrequent presence at the project office at Andasibe. Albert preferring instead to work at his home in the larger town of Moramanga, otherwise, he was busy traveling to Antananarivo, the capital, to attend administrative meetings. This arrangement left Hery with real control over the ICDPs daily operations. His role entailed hiring and laying off staff (for hiring, Albert was present, but Hery wielded greater influence in decision-making), delegating and overseeing tasks of the staff members, evaluating employees, approving promotions and demotions, checking daily revenues from tickets sold to tourists entering the reserve, drawing up annual budgets, and attending meetings with the heads of various project components, including the Deputy head of project, the representative of SAF-FJKM (the Malagasy development NGO), and the "tourism development" leader.

Herisoa was ambivalent about the overall success of the project, skeptical of ANGAP's takeover, and cynical about Albert's distance from the project's daily operations:

If we say we've succeeded, we don't see concrete results. If I say we haven't succeeded, still there are little things that the project has accomplished. The problem in Madagascar is that it's the Malagasy-the owners-who destroy. For example, in Andasibe, it's the leaders in the Direction des Eaux et Forêts who send men out to steal wood. They pretend to catch them afterwards. The foreign NGOs...only designate a manager and let him do what he wants. He [the foreign agent] has full blind confidence in the Malagasy director, even if there's something that's not right with what this manager is doing.

Despite workers' general cynicism about the future of forest conservation, the ouvriers and agents de conservation vowed commitment to their work, a belief in the purpose and methods of forest conservation. The tourist guides (twenty-five men and four women) of Andasibe were not project employees but freelancers. They enjoyed their work and relied on the continued existence of the forest for their livelihoods. I occasionally heard rumors of certain guides stealing animals and insects from the Special Reserve to sell to foreigners. From my perspective, they seemed serious about their job and sought to improve their scientific knowledge of flora and fauna. In Madagascar, visitors who buy package tours arrive at national parks in a sports utility vehicle with driver and their personal guides. But the many tourists who travel independently typically arrive by taxi-brousse. The Andasibe guides vied with each other for these fares (figure 6). They usually circulated around the three tourists hotels in Andasibe, offering to lead tourists on night visits into the reserve to see the 
nocturnal animals, or to arrange early morning pick-ups into the larger Mantadia forest. As a group, the guides knew French, English, Japanese, Italian, and German. Those with strong language ability tended to get more fares. A few were well-versed in the taxonomic and common names of species and the medicinal properties and popular legends of endemic trees and plants.

The guides refused to become employees of the project because they feared a drop in their income and a restriction of their freedom. One guide told me that ANGAP offered guides a salary between 150,000 and 200,000 FMG (\$30-40) per month. But the high tourist season yielded daily incomes for guides of 100,000 FMG (\$20). In 1996, the Andasibe guides formed an association. The association aimed to strengthen their standing and to dissuade individuals from accepting official guide positions from project management, which would have undercut the position of the others.

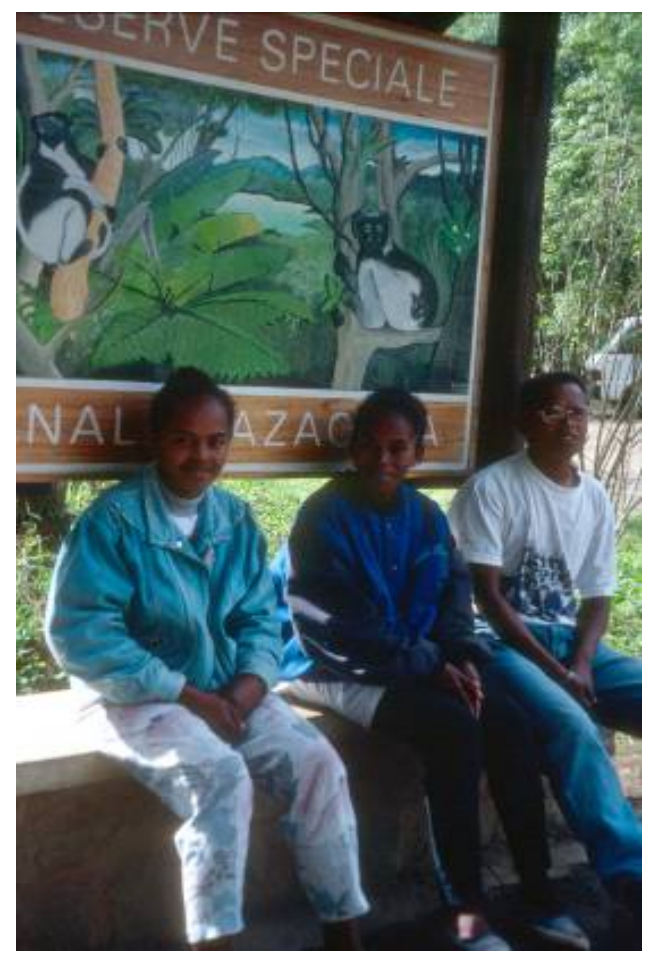

Figure 6. Guides waiting for tourist-clients at the entrance of the Special Reserve of Andasibe (Credit: Genese Sodikoff, 1997).

\section{Conservation and the Subject of Rights}

The words used by the ICDP workers as they recounted moments leading up to the strike offer insight into the extent to which they strategically deployed environmentalist values, as well as assimilated such values. In the late twentieth century, environmentalism appeared to have reanimated a discourse of worker rights in Madagascar, as revealed through an examination of workers' stated demands.

Unlike the guides, ICDP workers felt unduly pressured by the demands of the project and constrained in their ability to protest difficult conditions. The manual work could be grueling, wages were insufficient, Albert was distant and disinterested, and the National Director exerted his authority oppressively, according to workers. The pressures of economic need and moral affront-a sense that workers' labor and self-respect were belittled by management-eventually prodded workers to take action.

I was interested in hearing workers' specific complaints against Hery and Albert beyond my personal knowledge of Albert's volatile personality, and Hery's harassment of certain employees. Alain, an agent de conservation, related more precise complaints against Hery. Although he was an agent de conservation, he was transferred from manual labor in the forest to ticket sales (as controlleur) at the Special Reserve entrance. His rank was second category (deuxième categorie), and forth or fifth echelon (quatrième ou cinquième echelon) he could not quite remember which. Once a year, it was possible to move up in category or echelon, but no one really understood the promotion 
system: "Behavior? I don't know... Behavior, punctuality... I don't know what to do to get promoted." Alain continued:

The Dir Nat said to me, do you want to be controlleur, do you prefer to be? I said "no." "Why," he says. Because the guys who work as agents de conservation in the forest have a lot of advantages... the knowledge of the forest, the flora and fauna. But here [as ticket-taker] there's nothing. Before, I knew a lot about the forest, but for three years I've stayed here [at the entrance]... Me, I'm a conservation agent. Most people who work in the park are. The species Propithicus [a lemur] exists here, but I've never seen it! I've never seen it...

Alain revealed a genuine interest in seeing and learning about the local fauna. His boss took away from Alain work enjoyment, or the opportunity to gain knowledge of wildlife species in a ecologically-oriented development job market - the chance to see a Propithicus, for example. This was a recurrent problem for employees, the way in which Hery did not reward workers' enthusiasm, interest, or diligence, and instead punished faults quickly and arbitrarily according to his mysterious set of guidelines. Workers, moreover, felt they could not rely on the bosses to uphold the work statute, which enumerated rights and benefits, such as paying at least the minimum wage. None of the employees received the official minimum wage until their strike in January 1997, nor did they earn promotions after favorable evaluations. Workers aspired to gain knowledge, to be treated respectfully and fairly, and to earn raises but were frustrated repeatedly. Alain explained,

Half the workers are afraid of the director. The director is a crocodile. For example, he's not sociable. He has the habit of targeting someone... When he became director here, his character changed. There's something that's not going right in this project. For example, when I signed my contract, I didn't know I had to work holidays. After I worked during these days, I thought I'd earn more-at holiday cost... I'd understand if the director were strict with the rules, but the other things he does... A mirror was stolen in the outhouse here. He made us guard the toilets; he thought someone would steal the sink. I lost dignity. It's the dignity of man!! [My research assistant giggles uncontrollably. Alain laughs as well.] It's true! In 1993, we had about thirteen people who planted eucalyptus every day in the park about ten kilometers away. Every morning we had to go on foot carrying eucalypts out there. For two months-it was hard! There weren't cars yet. Normally we should have gotten tents, but I think [they made us come back every evening] to avoid having to pay an indemnité de déplacement [a per diem for extended outings]...

The chronology of workers' disputes with management in late 1996 and early 1997, and my interviews in the summer of 1997, made it difficult to decipher whether Alain's phrase, "the dignity of man," was part of his linguistic repertoire before the Andasibe workers' strike and contact with the national Trade Union Center ${ }^{5}$ (Syndicate National) in Antananarivo, or whether these experiences of organized resistance reinvigorated an older, French rhetoric of rights. In either case, it was notable that Alain's words combined a labor discourse with a sort of species fetishism common to eco-tourists and conservation consultants. The combination of concepts revealed the way in which workers linked conservationist ideas to labor rights.

Workers' complaints about management focused on the National Director and often stressed Hery's wrongs by associating his behavior with conservationist concerns. Workers alleged that Hery was illegally involved in the timber business, which Alain felt was morally reprehensible given Hery's forestry background. The workers mistakenly claimed that foresters in Madagascar were obliged to swear off the timber business. Alain's insistence upon this point seemed somewhat disingenuous given my knowledge of a 1994 project scandal. At this time, Hery orchestrated an illicit

5 In Madagascar today there are eight national trade union centers, including Fivondronamben'ny Mpiaga Malagasy (FMM) with a total membership of 30,000, Union Syndicats Autonomes de Madagascar (USAM) with a total membership of 2,706, Sendika Krtianina Malagasi (SEKRIMA) with a total membership of 5,000, Fédération du Travailleurs Malagasy Revolutionnaires (FISEMA), Cartel National des Organisations Syndicale de Madagascar (CARNOSYMA) is affiliated to the OATUU, Fédération des Syndicats de Travailleurs de Madagascar (FISEMARE) with a total membership of 60,000, Sendika Revolisakonera Malagasy (SEREMA), and Union Syndicale des Travailleurs et Paysans Malagaches (USTPM). Statistics from the Ministry of Labour indicate that less than ten percent of all workers are unionized. This is largely due to the fact that eight percent of the workforce is engaged in subsistence agriculture (http://www.icftuafro.org/public/ProfilesEN.pdf). 
operation in which Andasibe project workers had been selling timber right out of the forest station. They had recourse to a convenient alibi: they were simply culling dead timber from the wake of Cyclone Geralda, but in truth they had been hewing living trees. At the time, Albert Slater, the Chief of Party, was embarrassed to learn that I knew of this affair which he sought to keep hidden from agents in the capital.

Hery’s daily actions and behavior also affected workers' physical being. Leonard, the ouvrier, complained that Hery had asked all workers to bring in their issued rain gear for a general inventory. That was in March. Three months passed, the cold season arrived, and the management never returned the rain gear to workers. Alain remembered the difficulties of building the crafts boutique at the reserve entrance, which the management had postponed until days before a USAID team was coming in from Antananarivo:

The Director called a meeting and said all the staff had to work hard. At this time, I was recovering from an illness, but because of the project, I came here to work-to do the rattan walls... At 9am I arrived. I worked a lot, a lot, a lot until 12pm. We had about 5 minutes for lunch. The project truck took us into the village and picked us up. At $6 \mathrm{pm}$ they let us get our dinner, 15 minutes. Until 3 am the next day we worked... If they [the management] had the possibility to save our respect, our loyalty... But all the bureaucrats from [town] went home. All of us from Andasibe worked until 3am. At $1 \mathrm{am}$ Mr. Olivier [the NGO's Malagasy administrator] came. Mr. Olivier is sociablenot like the Director. All the ouvriers took advantage of his arrival. "Give us hot tea, coffee, rum, because we're busy and tired..." He said, "do your work, and we'll see." Ton ton ton [the sound of hammers] - the work was done. Afterwards, not even a word of encouragement or thanks, nothing — not even [from] the Director.

Most of the workers appreciated the occasion to discuss work-related problems with me. There were exceptions. A couple of employees feared jeopardizing their positions and presumably felt that speaking to me might displease the National Director if he should find out about it. For example, Charles, the project orchid keeper, seemed reticent to critique his bosses but proud of his self-motivated conservationist activities.

Charles was classified as an agent de conservation. Originally schooled in metal work, he received a short training in orchid propagation in 1977. In the early 1990s, he built lemur cages for scientists in Andasibe who were unsuccessfully trying to breed lemurs in captivity. Then Charles was hired by the project to breed and tend orchids, and to scout for them on trees strewn on burnt land. He appeared to enjoy his work and redirected my questions away from managerial practices.

Genese: The director likes orchids, doesn't he?

Charles: Yes, he used to raise orchids. Before the project, I saw some orchids at his house. But I don't know if he still has any. After the orchids flower, if the seed is ripe, is when you take the seeds. There are monopodial orchids, terrestrial orchids...

Charles enthusiastically told about an association he and his wife formed in his village which aimed to teach farmers agroforestry methods and alternatives to tavy for a livelihood. He claimed to "do it for pleasure, not pay." Charles participated in the worker strike in January of 1997, but did not join the union formed immediately afterwards. He was a mild mannered man, content with his solitary and quiet job, as well as his relatively high salary (approximately 350,000 FMG [\$70] per month). He seemed a favorite of Hery, and they had a good rapport.

For the majority of workers, Hery's arbitrarily strict behavior was demoralizing. In late December of 1996, a group of workers from another conservation project visited Andasibe. Discussions with visiting workers revealed to Andasibe workers the extent to which they were disadvantaged. Their wages were comparable, but living expenses in Andasibe were much higher. The crucial difference was the regular training visiting workers received, which included species identification, forestry technology, and visits to other national parks, all of which were unknown privileges to Andasibe workers.

Workers wrote a letter, a list of demands, which they delivered to Albert Slater in January of 1997. Workers apparently retyped their letter, which I will describe in time, in a more formal fashion several weeks later, after they had formed a union. (The chronological order of events related to me separately by four workers was somewhat confusing and inconsistent.) Andry, another project worker, related the details of the events around the time workers delivered, or tried to deliver, the 
original letter of demands to Albert. Hery obstructed their communication with Albert and tried to confiscate the letter.

We wanted to talk to the Chief of Party [Albert Slater], but the Director and Mr. Olivier prevented us from talking to Albert. We insisted on talking to Albert and finally he came... The director didn't let Albert speak to us directly, but was always next to him... We [had] sent a letter [in French] to Albert, but it was the Director who got the letter first, and he read the letter. He translated; it was he that would speak to Albert... The director said, 'you, you don't know how to speak French. You can't speak to Albert because you don’t speak French.' [My interview with Andry was conducted in French]

Hery and Mr. Olivier from the NGO attempted to silence workers and successfully intimidated the majority, who did not want to risk further disobedience, into resuming their job duties. Furthermore, the work of maintaining a scenic and accessible environment for eco-tourists is not the sort of production process that can be dismantled with a strike. If a worker strikes in the forest does he make a noise? Several workers realized they had to state their demands to higher authorities in the capital. Three employees took vacation days to travel secretly to the ANGAP office in Antananarivo where they presented their case, explaining their need for higher wages, issued work gear, and training, and citing unfair managerial practices. They were well-received by the head administrators at ANGAP, the Directeur Générale, Directeur Financier, and the Directeur Administrative, who pronounced that the workers "had the right" to demand the NGO's statute de personnel, a document that was supposed to describe benefits, rules of conduct, penalties, and the promotion system. But workers had never seen the statute; as Andry explained, "all was hidden. There were a lot of things the employees didn't know."

For his part, Hery was furious when he discovered the union delegates had gone to the ANGAP headquarters. After their visit to ANGAP, workers demanded to see the NGO's statute de personnel, as none of the workers had received a copy of it when they signed their original contracts. Andry explains,

We asked for the statute first, and then they didn't want to give it to us right away. We kept asking for it and the Dir Nat ... he didn't directly say 'yes' or 'no.' In the end, as we didn't yet have the union, we informed ourselves of what we had to do to get the statute. We got information at the Syndicate of Madagascar-the head office. What can we do? Can we form a union here in Andasibe? They said, "yes, it’s possible. But you must follow these steps...." There were a lot of papers to fill out.

Raymond and Andry had been familiar, (it is not clear to me how), with the existence of the Syndicat National in Antananarivo. The Syndicat's office is a small, unapparent room on top of a horse race betting establishment, and its tumbledown interior contrasts dramatically to the wellendowed offices of ANGAP. Discussions with the director of the center enlightened workers about the national work code (Code du Travail 1995). They regretted not having organized before the final months of the project, but earlier they "didn’t know [they] had rights."

After filling out the requisite forms, the union delegates presented the paperwork to Hery, the "Dir Nat", who was required to sign the document. For management, matters were getting out of control. Hery was not able to prevent workers from confronting Albert in the end, since Albert passed by the Andasibe office two or three times per week for about an hour. Andry's narrative reveals what was at stake for both Hery and Albert, both of whom needed to secure ongoing job positions during the transfer period when the NGO's contract ended and ANGAP resumed control. Albert tried to keep matters internal. During discussion about unfair wages, Andry remembers that Albert Slater scolded him for publicizing salary amounts: "Albert said 'nooooo Andry, you mustn't talk about Fanja's salary in front of everyone because it sounds like your jealous, and what will Fanja think?'" Obviously affected by Albert's insinuation that Andry was petty (Albert was probably anxious not to draw attention to his own American salary), Andry insisted to me that he was not trying to bicker over varied salary amounts but over the unfair classification system, and the fact that promotions required favorable evaluations that never took place. Andry continued,

We continued to demand the statute [from the NGO], and they gave us the statute. But we said it wasn't real; we found it wasn't complete. There were things in it, missing things; they put other things in it. And in two weeks they gave us two different statutes. And we didn't know anymore which was the real one... 
Although the Directors at ANGAP's headquarters were initially supportive of Andasibe workers' attempt to obtain the NGO's statute de personnel, their attitude changed when they discovered that Andasibe workers had formed a union and were awaiting Hery's signature on the official document. Andry related the exchange that occurred between ANGAP Directors and two union delegates who later returned to the ANGAP offices:

Now ANGAP said, "if you make a union, it's a reason for closing the enterprise [at Andasibe]. And if we shut down, what will you do with your union?" We said that we did it because we saw that there were things that were not normal at work, and they don't give a damn about all that... We're waiting... for the letter on July 15... I asked the question, "you know that it's the villagers who can protect this forest. If you get rid of all the people from the village at work here, they'll go and cut down the trees. That's for sure. Because no one can protect that. It's themselves that can destroy it..." They didn’t believe it.

I could not find out the precise reasons for the adamant anti-unionism of the ANGAP directors; unions presumably conflicted with international donors' economic ideology and policy. Despite his equivocation, Hery ultimately signed the union document prepared by delegates. Union members then typed a formal summary of the preceding meetings with management. Presumably the trade union center representative counseled delegates to formalize their demands, which had more weight after the trade union center officially recognized the union's existence. The workers' formal letter to management, signed February 3, 1997, demanded a 170-175 percent pay increase dating back thirteen months. They wrote:

For numerous reasons, our current salaries are not sufficient to cover our daily needs. The poverty of agents continues to worsen. For example, most personnel cannot manage to acquire new clothes and are considered badly attired. Moreover, many of us are in debt. In short, it is impossible to save.

Workers asked for a special fund for agents who work regularly in the forest and "risk the loss and wear of their personal belongings" and argue that a "special fund" for work clothes and shoes "would be very much desired, and would encourage the motivation of agents." The letter tabulates the prices of rice, beef, oil, sugar, and salt, as well as the amounts needed for a typical four person family in Andasibe. It lists the expensive housing costs in Andasibe, specifying rent for a house without electricity, for one far from the road, for one in poor condition near the road and in the village, and for a cement house with electricity but no water. It calculates cost of living increases in proportion to wage increases since 1992. Its authors point out that the project's medical benefits entail an 80 percent reimbursement for medicine but not for transportation fares to [town] for serious illness: "we know that our salaries do not allow for our alimentary needs and do not allow us to buy medicine when ill... we must borrow."

The strike in January, the formation of the union in February, and the formal letter of demands signed by management in February resulted in a two-month, rather than thirteen-month, retroactive pay increase for workers applicable to the end of the project. The raise was less than workers had hoped. Even the Syndicate of Madagascar was demanding an increase in the national minimum wage from 121,000 FMG (\$24) to 450,000 FMG (\$90) per month in order to keep in step with the rising cost of living, but prospects of the Syndicate's victory over the state were slim. In addition to doubled wages for Andasibe workers, Hery gave each worker "a gift," a pair of plastic sandals to wear on the job.

Workers believed that the creation of their union had sparked ample fear in Albert, Hery, and other ANGAP officials, all of whose jobs depended on USAID's approval rating. It was in Slater's best interest to maintain good relations with Hery, his counterpart, as well as with other high-ranking Malagasy colleagues in the conservation bureaucracy in order to keep his options open for future job contracts in the country. Workers hoped their strengthened position would grant them a measure of job security. Nevertheless, almost all wage workers were uneasy about ANGAP's imminent takeover in July of 1997.

A team of ANGAP representatives from the capital had descended on the Andasibe project to interview the personnel about a month before my arrival. The ANGAP representatives explained that ouvriers, guardiens, and femmes de ménage would need at least a junior high school certificate, agents de conservation would need a baccalaureate (a diploma of successful high school completion), 
and guides would require a baccalaureate and at least two foreign languages. Few of the employees had these qualifications, which made them apprehensive before ANGAP's visit.

\section{The Practice of Marginalization}

I have suggested that neoliberalism has created conditions in which the expression of environmentalist values affords workers greater leverage in bargaining than does the rhetoric of human rights. The workers at Andasibe appeared on the one hand to have embraced the environmentalist's moral perspective of endangered species (see Agrawal 2005), while on the other hand articulating such views offered a potential means of moving up in the project.

The subject of human rights remains an integral part of current conservation strategy, however, insofar as the ICDP approach recognizes and seeks to ameliorate human poverty. Yet in having assimilated the critique of conservation and development into current environmental programs, policymakers have contained the spaces in which "rights discourse" circulates (see Ferguson 1990).

The conservation and development approach champions the view that people have the right to have their basic and natural resource needs fulfilled, as well as their livelihoods improved. A proletarian "rights discourse," in contrast, appears politically and economically retrograde. In light of current ecological and economic conditions, it seems even superfluous. A conversation with two consultants to the Andasibe-Mantadia ICDP describes one of the innumerable, ordinary ways in which the subject of labor rights, and so actual labor rights, were devalued.

I had the opportunity to speak to the two American consultants, Kathy and Bill, working with the project before its transfer to ANGAP. Both had served respectively as the director and technical advisor of another integrated conservation and development project in Madagascar, so they had a comparative perspective. They confessed that Anala managers considered the guides in particular to be a big problem. Bill stated that although the guides here were not "so bad" compared to those at other parks, they still overcharged tourists and lacked motivation. Bill asked me rhetorically whether I, as a tourist visiting a park, would choose a park guide "looking sharp" in an ANGAP uniform, or a guide from among the "bandits," the unofficial guides, drinking and playing cards?

Rather than concentrating on the problems plaguing this project-they never divulged any knowledge of the strike in January or the existence of the union-Bill and Kathy emphasized general problems they considered intrinsic to conservation efforts in Madagascar. For example, Bill pointed out that Madagascar's conservation projects were unable to show a clear link between conservation and development: that is, there was no direct economic benefit for local residents to preserve the forest. I sought to elicit Bill and Kathy's perspectives of the wage workers:

Genese: If ANGAP lays off people here, what will they do?

Bill: $\quad$ Listen. Everyone knew it was a three year contract...

Kathy: Yeah, not for life.

Bill: I think it's a little harder that [Madagascar] was socialist before because everyone had a job...

Genese: It's possible that when people get laid off they'll go into the forest.

Kathy: I doubt if they will. I think it's a threat.

During our conversation, Kathy and Bill were duly sympathetic of workers' fears but downplayed workers' threat to burn the forest down if laid off. Moreover, Bill and Kathy seemed somewhat suspicious of my pro-worker standpoint and skeptical of my research focus. Three times, Bill mentioned what he thought would be an "interesting research project" for me, such as the problem of sapphire miners in the Amber Mountain Protected Area, or the constant miscommunication between ANGAP representatives in Antananarivo and at project sites, a problem which fostered unnecessary worries. While these suggestions might have been well-intentioned, they also reflect a tendency for conservation representatives to dismiss labor issues. Bill and Kathy veered the discussion toward what they thought were the fundamental problems threatening sustainable conservation, such as the project's bloated pay roll, ANGAP's insufficient revenue to run the park system, the lack of a surefire way to show local tavy farmers (figure 7) the advantages of conservation, and low levels of environmental knowledge and education among workers and guides. Regardless of their critical views of the lower-tier workers, which may or may not have been justified, the tendency to dismiss the matter of labor seemed at odds with the daily concerns of the project administrators. Labor issues constantly hindered project operations. For example, during the final month of the NGO's contract, Bill had hired a crew of workers to supplement the regular staff at the going rate of 5,000 FMG (\$1 US) per day. Apparently, the regular crew was insufficient to complete the numerous last minute tasks at hand, yet ANGAP was planning to cutback the manual labor force. 


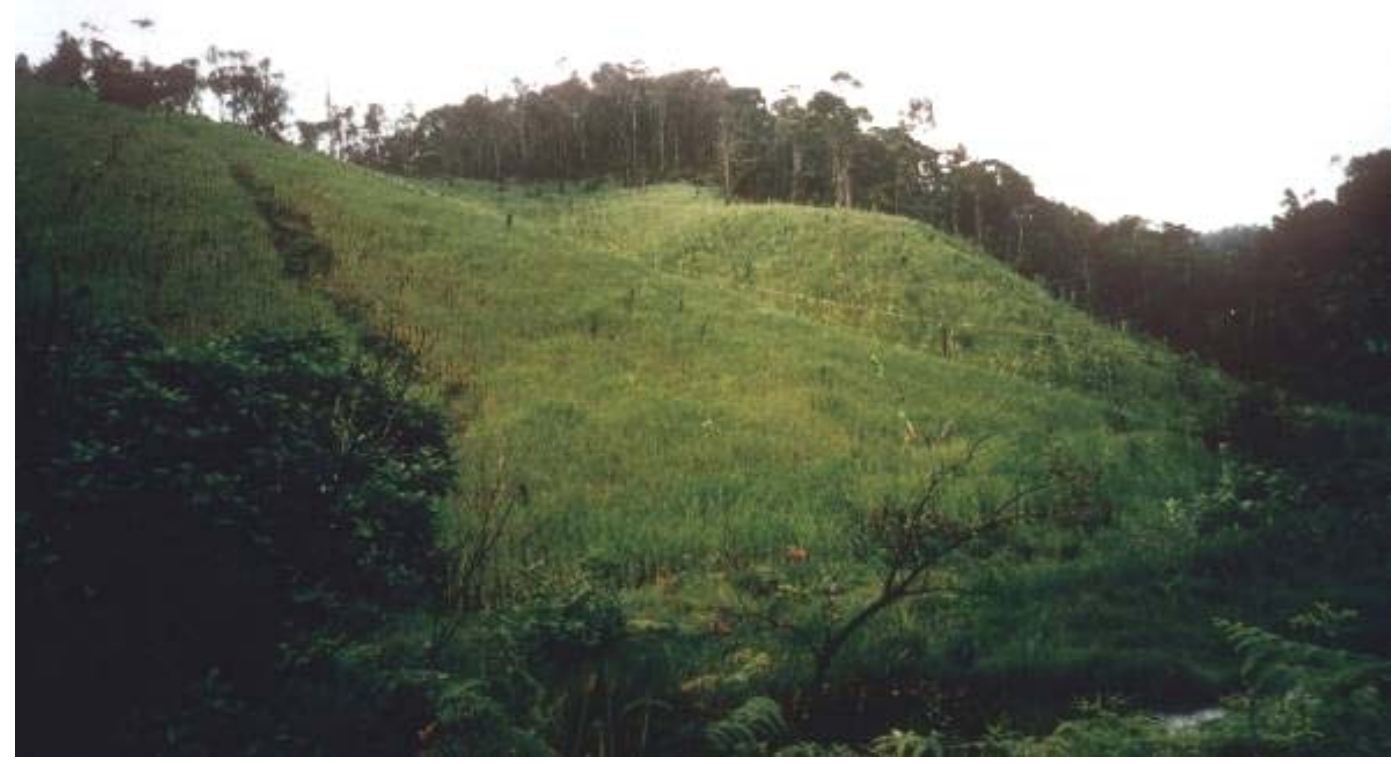

Figure 7. Tavy parcel in the Mantady forest (Credit: Genese Sodikoff, 1995).

The consultants were complimentary of Hery and stressed ANGAP's heartfelt desire to keep everyone employed. They had resided at Andasibe for a total of two and a half months at the time I spoke with them. I had the impression that they uncritically accepted Hery's and Albert's opinions about the workers and guides. Bill and Kathy's claim that all workers knew from the beginning that their length of employment with the NGO would last no more than three years deserved investigation. Leonard brought me his signed contract with the NGO. Under length of employment, it was marked: "durée indeterminée." In fact, all the workers had signed a contract with the NGO for an indeterminate length of time. Workers plausibly figured that their jobs were secure, since they had been forest service employees before the NGO's arrival, and expected that the NGO would get a renewal contract, or that another foreign organization would fund the site, as the UNDP, the World Bank, Japan, and Norway had done previously at Andasibe.

Managers' tendency to portray wage workers as poorly educated, unreasonable, or unrealistic not only provided a rationale for dismissing labor disputes but also prevented managers from recognizing workers' contributions to the project. The Andasibe-Mantadia project looked to education and technology for sustainable capitalist development and conservation. Albert and Hery were eager to acquire technological resources, such as updated aerial photography, geographical information system software, and video equipment for an interactive ecological learning center. The project paid for the services of numerous tropical ecology and park management consultants, and it supported a surfeit of well-educated employees (mostly Hery’s kin). Conservation managers at Andasibe-Mantadia relied on high technologies to create an appearance of project success, hoping that sophisticated-looking trappings (figure 8) would distract project evaluators from fundamental infrastructural failures of the project. In 1995, a Swiss forestry consultant advised Albert, to his delight, that all he needed to do to satisfy ANGAP was to place "No Trespassing" signs along the perimeter of the Taloha forest, as ANGAP representatives were easily bedazzled by professional looking placards. Later, this same Swiss forester resigned his partnership with the NGO and canceled his contract when he realized the scope of the NGO's incompetence regarding forest conservation. 
He complained that the NGO had failed to carry out a single one of his recommendations, that the agents de conservation were inadequately trained and lacked able direction and therefore failed to detect evidence of graphite probing within the Mantadia National Park.

From 1994 to 1995, Albert complained that his report-writing duties and successive consultant visits made it next to impossible for him to oversee the project. According to one Malagasy project partner, the degree to which Albert's reports to donors inflated the project's minor accomplishments were inversely proportionate to the NGO's actual productive input. The distribution of resources, patterns of residence, labor practices, strategic foci, and intimations of lay offs enumerate tactics of devaluation by the NGO, ANGAP, and USAID agents. Conservation planners and managers not only depreciated the social being of conservation wage workers, but they also disregarded the significance of workers' social roles, including their positions as friends or kin of tavy farmers and loggers in Andasibe, and their ability to gain the necessary trust of peasants in more distant villages near the Mantadia forest. As the project brought in Merina elites from town or the capital, as well as American consultants and managers, ANGAP representatives made workers and guides anxious with hints of potential lay offs and their plans to take over the tourist guidance business. ANGAP directors, the former Merina officials of Eaux et Forêts, had no sense of loyalty to their longstanding employees. Raymond, the lead union organizer, remembered what the union delegates argued to the head directors of ANGAP in Antananarivo:

We said, "we can't accept that you'll take over Andasibe with new people from Antananarivo because we are the ones who have worked here for years so that this reserve is still the way it is. Why would you bring someone that has not made himself weary with labor in Andasibe?" If ANGAP doesn't hire the Andasibe employees, we'll be obliged to fight because we're the ones who have taken the pains to make the place beautiful.

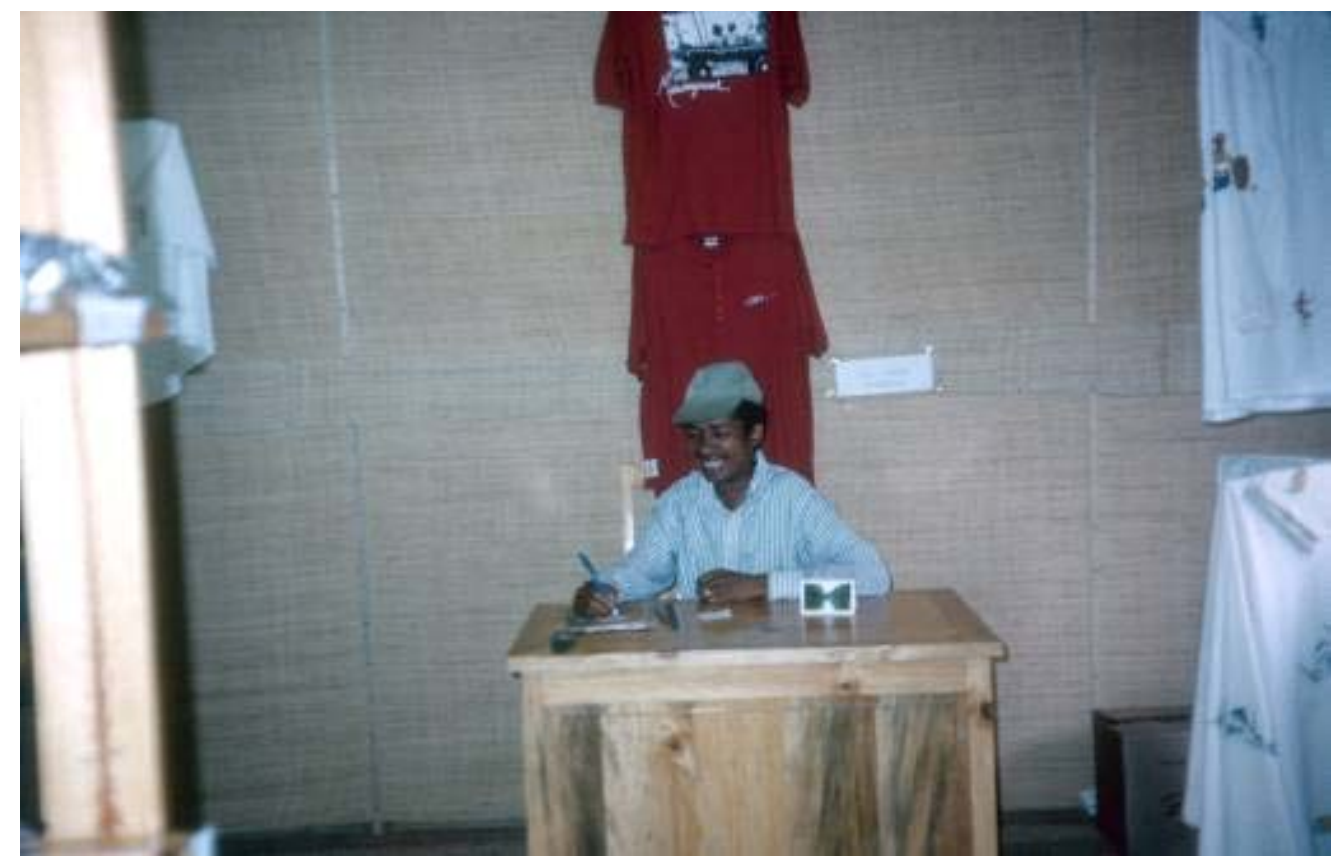

Figure 8. A conservation agent takes on new duties selling items in the tourist gift shop of the ICDP (Credit: Genese Sodikoff, 1997).

Herisoa emphasized that only Andasibe workers could adequately protect the local forest: "As soon as these workers are unemployed, there won't be any more prevention of forest destruction. This Reserve will be destroyed because it's people from Antananarivo who will work here. They don't yet know and they'll not know the areas where the thieves usually look for wood. The time it takes to learn this will be enough for the loggers to ruin the Reserve." Naivo, another ouvrier, explained the workers' collective stance: "The project has done a good job up to now, but the problems are the future of the employees who can sabotage [the project] if they're not hired by 
ANGAP." Although burning down the forest would constitute overt sabotage, local residents' economic pressures would indirectly sabotage the project in the long-run. As Herisoa pointed out "the employees who are not hired will become loggers because one can only do that to survive in Andasibe."

\section{Epilogue to a Strike}

In July of 1997, paperwork from ANGAP arrived declaring the employees who would be retained or dismissed. Most of the Andasibe staff were kept, which averted an angry demonstration. Hery announced to the crew "not to worry," that he "was still their parent." (The manual workers scorned Hery's paternalism.) Still, the dreaded letters from ANGAP announced unsettling readjustments of positions and corresponding wages. The World Bank had just apportioned a generous sum to ANGAP with stipulations of cutbacks. At Andasibe, cutbacks materialized in workers' wages but not in the reduction of the surfeit of highly educated bureaucrats. I saw Leonard, the diligent ouvrier, shortly after the announcements were made. He said he had been assigned to forest surveillance work with a pay raise of 4,000 FMG per month, equal to about 80 US cents. He laughed about it bitterly. He explained that ANGAP's work benefits, such as lodging and extended outing indemnities, were even less than the NGO's had been. Two of the union delegates received letters of "no engagement" with ANGAP. Unlike Raymond, the dynamic union organizer who was very popular among his co-workers, the two laid-off delegates had been less beloved and influential within the crew. In total, five of the 39 wage workers were laid off by ANGAP, and one of the fourteen bureaucrats was laid off, a blow to Hery, but this family member was able to obtain temporary employment with the NGO.

The five official guides chosen were the biggest surprise. They included Raymond, the main union organizer, Alain, the ticket-taker, one adept guide out of the 29 member guide association, and two other agents de conservation. What was really shocking was their new salary: 500,000 FMG per month. This was the highest wage among the non-bureaucrats, and a significantly higher wage than ANGAP had speculated to the guides earlier. It was also higher than the salary of guides another National Park in southern Madagascar; they earned 377,000 FMG monthly. ANGAP claimed it intended to standardize the wages of all Protected Area job positions, so the 500,000 FMG wage for official Andasibe guides may have been a temporary ploy to anger the freelance guide association. Everyone was on a three month trial period, however, after which time ANGAP could again alter salary amounts. A couple of the old-timers received severe wage reductions. I was told that Charles, the loyal orchid keeper, had his wages cut by 100,000 FMG per month. In response, he cried.

\section{Conclusion}

In July 1997, a young American woman in the USAID office of Antananarivo acted nonplussed when I mentioned the strike that occurred six months earlier at Andasibe. "All of the projects have had strikes," she said, referring to the ICDPs. I elaborated and sparked some interest: "They formed a union?" she repeated.

Her words unveiled the normative nature of an apparently out-of-the-ordinary event. The event of the strike was treated as an anticipated, temporary glitch in ICDP operations. That the workers at Andasibe had taken it to the next level, unionization, gave them a brief moment of recognition, if only in the surprised response of an expatriate consultant. Otherwise, ICDP bosses had ensured that grant managers and environmental officials remained ignorant of these troubles at the workplace, not wanting to risk their potential to gain job contracts down the road. It is also unlikely that the workers' complaints would have elicited any sympathy from environmental authorities, since ICDP workers enjoy privileges unknown by the unemployed majority in Madagascar.

The mid-1980s marks a point in Madagascar's history when externalities thought to have inhibited the success of state conservation efforts in the past-people who made their livelihoods from forest resources-were formally incorporated into the conservation effort. As both targets and implementers of conservation, manual conservation workers are in the best position to judge conservation on moral grounds as not only a vision of the ecological future but as work replete with meaning. Manual workers' intermediation of peasants and environmental planners in the conservation endeavor, and their subjective assessment of this role, exposes the contradictions of ecocapitalist development. When we apprehend the rain forest as conservation's workplace, we may relocate "resistance" from outside the institutional purview to inside it.

Environmental planners have not positively valued the labor of manual workers in ICDPs, in spite of these workers' fundamental role in putting plans into action on the ground. Evidence of manual workers' marginal status in the conservation bureaucracy lies in their small numbers relative to the size of protected areas, the insufficient task load of manual labor, and its low wages relative to the wages of intellectual conservation labor (including planners, consultants, and scientists). When 
labor disputes occur in projects, managers attempt to silence workers' complaints through intimidation and by the omission of labor-related issues in project documents. Officials and planners in the capital either trivialize or are ignorant of site-specific labor conflicts.

What are the effects of workers' sense of devaluation? Conservation and development institutions foster conditions in which low-wage workers feel greater allegiance to subsistence farmers than conservationists. Moreover, job insecurity and low wages compels them to maintain a foothold in the subsistence economy, and at many protected areas, they divert their energies from project work to slash-and-burn agriculture and cash cropping (the focus of my subsequent research in McNamara-Nord, Madagascar). While ICDPs strive to ensure the collaboration of target populations by delivering small-scale, compensatory development projects, building the capacities of villagers to partake in the tourism market, and nurturing a sense of investment through participation, they also construct a labor hierarchy that revives colonial-era arrangements while disavowing Malagasy workers' sense of entitlement to rights won through historical struggle. This brief history of an unusual and ultimately ineffectual strike at Andasibe raises serious questions about whether the distribution of finances for conservation and development can--or even intends to--realize programmatic objectives.

\section{References Cited}

Agrawal, Arum 2005 Environ mentality: Technologies of government and the making of subjects. Durham: Duke University Press.

Auer Bach, Eric.

2003 [1953]. Mimesis: The Representation of Reality in Western Literature. Princeton: Princeton University Press.

Barrett, Christopher B.

1994. "Understanding Uneven Agricultural Liberalization in Madagascar." The Journal of Modern African Studies 32(3): 449-476.

Bernard, William. 1984 "Soil Erosion, Conservationism and Ideas about Development: A southern African exploration, 1900-1960." Journal of Southern African Studies 11: 52-83.

Bernard, William 1989. "Introduction: The Politics of Colonial Conservation." Journal of Southern African Studies 15(2): 143-162.

Brockington, Dan. 2002. Fortress Conservation: The preservation of the Mkomazi game reserve, Tanzania. Bloomington: University of Indiana Press.

Brosius, J. Peter. 1999. "Green Dots, Pink Hearts: Displacing Politics from the Malaysian Rainforest." American Anthropologist 101 (1): 36-57.

Brosius, J. Peter, Tsing, Anna Lowenhaupt, and Charles Zerner, eds. 2005. Communities and Conservation: Histories and politics of community-based natural resource management. Walnut Creek: AltaMira Press.

Bryant, Raymond L. 1996 "Romancing Colonial Forestry: The discourse of 'forestry as progress' in British Burma." Geographical Journal 162(2): 169-178.

Carrier, James G., ed. 2004. Confronting Environments: Local Understanding in a Globalizing World. Walnut Creek, CA: AltaMira Press.

Code du Travail, Fehezan-Dalana Momba Ny Asa. 1995. Journal officiel de la Republique de Madagascar, No 2324, Sept. 25. Antananarivo: Foi et Justice.

Cole, Jennifer

2001 Forget Colonialism? Sacrifice and the Art of Memory in Madagascar. Berkeley and Los Angeles: University of California Press.

Cooper, Frederick. 1996. Decolonization and African Society: The labor question in French and British Africa. Cambridge: Cambridge University Press.

Covell, Maureen. 1987 Madagascar: Politics, economics and society. London: Frances Pinter.

Dove, Michael R. 1992. "Foresters’ Beliefs about Farmers: A Priority for Social Science Research in Social Forestry." Agroforestry Systems 17 (1): 13-41.

Dove, Michael 
1994. "The Existential Status of the Pakistani Farmer: A Study of Institutional Factors in Development." Ethnology 33(4): 331-51.

Dove, Michael

2005. "Shade: Throwing Light on Politics and Ecology in Contemporary Pakistan." Political Ecology across Spaces, Scales, and Social Groups, edited by Susan Paulson and Lisa L. Gezon. New Brunswick: Rutgers University Press. Pp. 217-238.

Egboh, Edmond O.

1979-1980 "Legal Efforts to Control Nigerian Forests Interest of the Metropolitan Economy, 1897-1940." Quarterly Review of Historical Studies 19(1-2): 64-90.

Escobar, Arturo

1997. "Cultural Politics and Biological Diversity: State, Capital, and Social Movements in the Pacific Coast of Colombia." In The Politics of Culture in the Shadow of Capital, edited by Lisa Lowe and David Lloyd. Durham: Duke University Press. Pp. 201-226.

Manassé Esoavelomandroso

1990 "La génération de Rainandriamampandry et la Révolution Française." In Ravao ny "La Bastille." Regards sur Madagascar et la Révolution Française. Guy Jacob, ed. Pp. 113-19. Actes du colloque d'Antananarivo, 5-6 June 1989. Antananarivo, Madagascar: CNAPMAD and distributed through Omaly sy Anio.

Feeley-Harnik, Gillian

1984 "The Political Economy of Death: Communication and Change in Malagasy Colonial History." American Ethnologist 11(1): 1-19.

Ferguson, James.

1990. The Anti-politics Machine: "Development," depoliticization, and bureaucratic power in Lesotho. Cambridge: Cambridge University Press.

Findlen, Paula 2005 The Two Cultures of Scholarship? Isis 96(2): 230-237.

Gezon, Lisa.

1997. "Political Ecology and Conflict in Ankarana, Madagascar." Ethnology, 36 (2): 85-100.

Ghimire, Krishna B.

1994. "Parks and People: Livelihood issues in national parks management in Thailand and Madagascar." Development and Change, 25: 195-229.

Ginzburg, Carlo.

1980. The Cheese and the Worms: The Cosmos of a Sixteenth Century Miller. Baltimore: The Johns Hopkins University Press.

Gown, Bonar A. 1997 "Admiral Didier Ratsirist Revolution." The Journal of Modern African Studies 35(3): 409-439.

Hanson, Paul W.

1997 The Politics of Need Interpretation in Madagascar's Ranomafana National Park. PhD Dissertation. Philadelphia: University of Pennsylvania.

Harper, Janice.

2002. Endangered Species: Health, illness and death among Madagascar's people of the forest. Durham: Carolina Academic Press.

Hayden, Cori.

2003. When Nature Goes Public: The Making and Unmaking of Bioprospecting in Mexico. Princeton: Princeton University Press.

Hodgson, Dorothy L.

2001. Once Intrepid Warriors: Gender, Ethnicity, and the Cultural Politics of Maasai Development. Bloomington: Indiana University Press.

Igoe, Jim.

2003. Conservation and Globalization: A Study of National Parks and Indigenous Communities from East Africa to South Dakota. Wadsworth Publishing.

Jarosz, Lucy

1993 "Defining and Explaining Tropical Deforestation: Shifting cultivation and population growth in colonial Madagascar (1896-1940)." Economic Geography 69 (4): 366-379.

Kull, Christian A.

1996. "The Evolution of Conservation Efforts in Madagascar." International Environmental Affairs, 8 (1): 50-86.

Kull, Christian A.

2004. Isle of Fire: The political ecology of landscape burning in Madagascar. Chicago: University of Chicago Press.

Larson, B. A.

1994. Changing the Economics of Environmental Degradation in Madagascar: Lessons from the National Environmental Action Plan process. World Development 22: 671-689. 
Levi, Giovanni.

1991. "On Microhistory." In New Perspectives on Historical Writing, edited by Peter Burke. Cambridge: Polity Press. Pp. 93-113.

Leymaire, Philippe

1975 "Le Fokonolona: La Voie Malgache du Socialisme." Revue Française d'Etudies Politiques Africains 112: 47-53.

Magnusson, Sigurdur Gylfi.

2006. "What is Microhistory?" History News Network. George Mason University. May 08.

Marcus, Richard R., and Christian Kull. 1999. "Setting the Stage: The Politics of Madagascar's Environmental Efforts." African Studies Quarterly 3(2), http://web.africa.ufl.edu/asq/v3/v3i2.htm.

Misser, François 2000 "Trade unions bite back." African Business 255: 31-32.

Moore, Donald S.

1993. "Contesting Terrains in Zimbabwe's Eastern Highlands: Political Ecology, Ethnography, and Peasant Resource Struggles." Economic Geography 69: 390-401.

Munro, William A.

1998. The Moral Economy of the State: Conservation, Community Development, and State Making in Zimbabwe. Athens: Ohio University Center for International Studies.

Neumann, Roderick P.

1996. "Dukes, Earls, and Ersatz Edens: Aristocratic nature preservationists in colonial Africa." Environment and Planning D: Society and Space 14:79-98.

Neumann, Roderick P.

1997. "Primitive Ideas: Protected Area Buffer Zones and the Politics of Land in Africa." Development and Change 28(3): 559-582.

Neumann, Roderick P.

1998. Imposing Wilderness: Struggles Over Livelihood and Nature Preservation in Africa. Berkeley: University of California Press.

Peltonen, Matti 2001 Clues, Margins, and Monads: The Micro-Macro Link in Historical Research. History and Theory 40(3): 347-359.

Peluso, Nancy.

1992 Rich Forests, Poor People: Resource Control and Resistance in Java. Berkeley: University of California Press.

Randrianja, Solofo

N.d. Le Parti Communiste de la Région de Madagascar, 1930-1939. Antananarivo: Foi et Justice, serie recherches historiques.

Revel, Jacques.

1996. "Micro-analyse et construction du social." In Jeux d'échelles. La micro-analyse à l’expérience, edited by Jacques Revel. Paris: Gallimard/Le Seuil. Pp.15-36,

Richard, Alison F. and Robert E. Dewar.

1996. "Politics, Negotiation and Conservation: A View from Madagascar." In Rainforest Conservation in Africa, edited by W. Weber, A. Vedda, and H.H. Morland. New Haven: Yale University Press.

Scott, James C.

1985. Weapons of the Weak: Everyday forms of peasant resistance. New Haven: Yale University Press.

Schroeder, Richard A. 1999. Shady Practices: Agroforestry and gender politics in the Gambia. Berkeley, CA: University of California Press.

Sharp, Lesley A

1993. The Possessed and the Dispossessed : Spirits, Identity, and Power in a Madagascar Migrant Town. Berkeley: University of California Press.

Sharp, Lesley A.

2001 "Youth, Land, and Liberty in Coastal Madagascar: A Children’s Independence." Ethnohistory 48.1-2 205-236

Sivaramakrishnan, K.

1999 Modern Forests: Statemaking and environmental change in colonial eastern India. Stanford: Stanford University Press.

Sodikoff, Genese 2005. "Forced and Forest Labor in Colonial Madagascar, 1926-1936. Ethnohistory 52(2): 407-435.

Taylor, J. 
1999 Aboriginal people in the Kakadu region: social indicators for impact assessment.

CAEPR Working Paper No. 4: 1-53.

http://www.anu.edu.au/caepr/Publications/WP/CAEPRWP04.pdf

Thomas-Slayter, Barbara P., Rocheleau, Dianne E.

1998. Gender, Environment and Development in Kenya: A Grassroots Perspective. Boulder: Lynne Rienner Publishers.

Thurow, Roger.

1991. "School A Good Deal on Island Off Africa: An ecological plan may save both from extinction; a woman brings schools." The Wall Street Journal. January 10.

Tronchon, Jacques

1986 L'Insurrection Malgache de 1947. Paris: Editions Karthala.

Tropp, Jacob

2003 "Displaced People, Replaced Narratives: Forest Conflicts and Historical Perspectives in the Tsolo District, Transkei." Journal of Southern African Studies 29 (1): 207-233.

Walley, Christine J.

2004. Rough Waters: Nature and development in an east African marine park. Princeton, NJ. Princeton University Press.

West, Paige.

2006. Conservation is Our Government Now: The Politics of Ecology in Papua New Guinea. Durham, NC: Duke University Press.

West, Paige, and Carrier, James G.

2004 "Ecotourism and Authenticity: Getting Away from It All?" Current Anthropology 45(4): 483-498.

West, Paige; Brockington, Dan; and Jim Igoe. 2006. "Parks and Peoples: The Social Effects of Protected Areas." Annual Review of Anthropology 35 (1): 14.1-14.27.

\begin{abstract}
The article presents a microhistory of a work strike in an Integrated Conservation and Development Project (ICDP) located in a rain forest of eastern Madagascar. ICDPs in Madagascar, as in other rain forest countries, are instruments of "green" neoliberal policy, a dominant development paradigm in Africa since the late 1980s. International donors and the Malagasy state are expanding the number of protected areas in Madagascar, and foreign NGOs typically manage the start-up phase of projects aimed at lessening slash-and-burn horticulture (called tavy) in the forest and to developing ecological tourism. The article traces the roles and narratives of low-wage, locally-hired ICDP workers, who perform the menial tasks of forest conservation. Details of a work strike by lower-tier ICDP workers in 1996 reveal dynamics of environmental interventions that have been neglected in analyses and evaluations. To understand conservation's recurrent failures, one must investigate not only the sources of tension between agrarian populations and park representatives but also those arising from conservation's historical division of labor.
\end{abstract}

Key Words: conservation, labor, capitalism, development, parks, Madagascar

\title{
Résumé
}

L'article présente une microhistoire d'une grève de travail dans un Projet Intégré de Conservation et Développement (PCDI) situé dans une forêt primaire de l'est de Madagascar. Les PCDIs au Madagascar, comme dans d'autres pays de forêt tropicale, sont les instruments de la politique néolibérale "verte," un paradigme de développement courant en Afrique depuis la fin des années 1980. Quand les bailleurs de fonds internationaux et l'état malgache éstablissent les aires protégées au Madagascar, les ONGs étrangères contrôlent la première phase des PCDIs. Elles mettent en application des politiques pour arrêter la culture sur brûlis dans la forêt (le tavy) et pour développer le tourisme écologique. L'article trace les rôles et les récits des ouvriers qui exécutent le travail manuel de la conservation. Les détails d'une grève de travail par les ouvriers du PCDI indiquent la dynamique des interventions environnementales qui ont été négligées dans les analyses et les évaluations. Pour comprendre les échecs récurrents de la conservation, on doit étudier non seulement les sources de tension entre les populations agraires et les représentants de parc, mais également ceux résultant de la division du travail historique.

Mots clès: conservation, main d'oeuvre, capitalisme, developpement, parcs, Madagascar 